\title{
BASAL SLIDING AND CONDITIONS AT THE GLACIER BED AS REVEALED BY BORE-HOLE PHOTOGRAPHY
}

\author{
By H. F. Engelhardt, W. D. Harrison, and Barglay Kamb
}

(Division of Geological and Planetary Sciences,* California Institute of Technology, Pasadena, California 91125, U.S.A.; and Geophysical Institute, University of Alaska, Fairbanks, Alaska 9970 I, U.S.A.)

Abstract. Bore-hole photography demonstrates that the glacier bed was reached by cable-tool drilling in five bore holes in Blue Glacier, Washington. Basal sliding velocities measured by bore-hole photography, and confirmed by inclinometry, range from 0.3 to $3.0 \mathrm{~cm} / \mathrm{d}$ and average $1.0 \mathrm{~cm} / \mathrm{d}$, much less than half the surface velocity of $15 \mathrm{~cm} / \mathrm{d}$. Sliding directions deviate up to $30^{\circ}$ from the surface flow direction. Marked lateral and time variations in sliding velocity occur. The glacier bed consists of bedrock overlain by a $\approx 10 \mathrm{~cm}$ layer of active subsole drift, which intervenes between bedrock and ice sole and is actively involved in the sliding process. It forms a mechanically and visibly distinct layer, partially to completely ice-free, beneath the zone of debris-laden ice at the base of the glacier. Internal motions in the subsole drift include rolling of clasts caught between bedrock and moving ice. The largest sliding velocities occur in places where a basal gap, of width up to a few centimeters, intervenes between ice sole and subsole drift. The gap may result from ice-bed separation due to pressurization of the bed by bore-hole water. Water levels in bore holes reaching the bed drop to the bottom when good hydraulic connection is established with subglacial conduits; the water pressure in the conduits is essentially atmospheric. Factors responsible for the generally low sliding velocities are high bed roughness due to subsole drift, partial support of basal shear stress by rock friction, and minimal basal cavitation because of low water pressure in subglacial conduits. The observed basal conditions do not closely correspond to those assumed in existing theories of sliding.

RÉSUMÉ. Sur le glissement et d'autres phénomènes au lit d'un glacier tels qu'ils sont révélés par la photographie de trous de forage. Les forages furent réalisés au Blue Glacier, Olympic National Park, Washington, dans une partie où le glacier a une épaisseur de $120 \mathrm{~m}$, une inclinaison de $12^{\circ}$ à la surface et une vitesse superficielle de $15 \mathrm{~cm} / \mathrm{d}$. Les images photographiques qui ont été prises au fond des trous montrent que l'on a pu atteindre le lit du glacier dans cinq occasions, en utilisant une perforatrice à câble. Les vitesses de glissement obtenues à l'aide de la photographie ont été confirmées par la mesure des inclinaisons dans les trous. Les valeurs observées varient de 0,3 à $3 \mathrm{~cm} / \mathrm{d}$. La moyenne est $1,0 \mathrm{~cm} / \mathrm{d}$, ce qui contredit les conclusions antérieures qui ont estimé la vitesse subglaciaire à une valeur voisine de la moitié de la vitesse superficielle $(15 \mathrm{~cm} / \mathrm{d})$. Les directions du glissement divergent jusqu'à $30^{\circ}$ de la direction du mouvement glaciaire à la surface. On a pu observer d'évidentes variations latérales et temporelles dans la vitesse du glissement. Le lit du glacier consiste en roc solide, couvert d'une couche active d'apport d'une épaisseur approximative de $10 \mathrm{~cm}$. Cette couche joue un rôle important dans le mécanisme du glissement. Elle forme une couche bien visible et mécaniquement individualisée, partiellement ou complètement dépourvue de glace, en-dessous de la zone de glace chargée en moraine à la base du glacier: les mouvements internes dans cette couche comportent le roulage de blocs coincés entre le lit et la glace. Les vitesses les plus grandes interviennent lorsqu'un décollement à la base de quelques centimètres se produit entre la base de la glace et l'apport morainique. Ce décollement peut provenir d'une séparation lit/glace due à la mise en pression du lit par l'eau de sondage. Le niveau de l'eau dans les forages atteignant le lit s'abaisse jusqu'au fond lorsque de bonnes connections hydrauliques s'établissement avec le réseau sous-glaciaire; la pression de l'eau dans ce réseau est essentiellement la pression atmosphérique. La vitesse du glissement est relativement faible à cause de trois phénomènes : (a) l'aspérité considérable du lit glaciaire créée par la couche active d'apport qui est intercalée entre le roc et le fond du glacier, (b) les cissions près du sol qui sont partiellement absorbées par la friction entre les roches, (c) la formation peu fréquente de cavités à cause de la faible pression d'eau dans les canaux sousglaciaires. Les phénomènes observés au fond du glacier ne correspondent pas aux conditions présumées par les théories du glissement.

Zusammenfassung. Uber das Gleiten und andere Erscheinungen am Gletscherbett aufgrund von photographischen Bohrlochaufnahmen. Bohrungen wurden am Blue Glacier, Washington, vorgenommen, in einem Gebiet, wo der Gletscher eine Dicke von $120 \mathrm{~m}$, eine Oberflächenneigung von 12 und eine Oberflächengeschwindigkeit von $15 \mathrm{~cm} / \mathrm{d}$ hat. Photographische Aufnahmen vom Grund der Bohrlöcher zeigen, dass der Felsuntergrund, über den der Gletscher gleitet, in fünf Fällen erreicht werden konnte, und zwar mit Hilfe eines Kabelbohrgeräts. Die Gleitgeschwindigkeiten, die sich aus diesen Aufnahmen ermitteln lassen, werden durch Neigungsmessungen in den Bohrlöchern bestätigt; sie reichen von 0,3 bis $3 \mathrm{~cm} / \mathrm{d}$ und sind damit nicht, wie bisher angenommen wurde, ungefähr gleich der halben Oberflächengeschwindigkeit, sondern wesentlich geringer. Die Gleitrichtungen weichen bis zu $30^{\circ}$ von der Fliessrichtung des Gletschers an der Oberfläche ab. Ausgeprägte laterale und zeitliche Änderungen der Gleitgeschwindigkeit treten auf. Das Gletscherbett besteht aus gewachsenem Fels, der mit einem etwa $10 \mathrm{~cm}$ dicken Schuttgeschiebe bedeckt ist. Diese Schicht unterhalb des Gletschers, welche teilweise oder völlig eisfrei ist, besitzt besondere mechanische Eigenschaften und ist aktiv am Gleitvorgang beteiligt. Bewegungsvorgänge innerhalb dieser Schicht

* Contribution No. 2908. 
schliessen ein Rollen von Felsbrocken ein, die zwischen dem gewachsenen Fels und dem sich bewegenden Eis eingespannt sin 1 . Die höchsten Gleitgeschwindigkeiten treten an Stellen auf, wo sich ein Spalt von einigen Zentimetern Breite zwischen der Sohle und dem subglazialen Geschiebe öffnet. Der Spalt entsteht möglicherweise durch eine Trennung des Eises vom Brett infolge des erhöhten Wasserdrucks am Grunde des Bohrlochs. Der Wasserspiegel in Bohrlöchern sinkt bis auf den Boden, wenn gute hydraulische Verbindung zu subglazialen Kanälen vorhanden ist; der Wasserdruck in den Kanälen entspricht im wesentlichen dem Luftdruck. Für die im allgemeinen geringe Gleitgeschwindigkeit sind verantwortlich (a) die hohe Bettrauhigkeit, die durch das zwischen Fels und Gletschersohle eingelagerte Schuttgeschiebe erzeugt wird, (b) die bodennahen Scherspannungen, die zum Teil durch Gesteinsreibung aufrecht erhalten werden, (c) die sehr geringe Hohlraumbildung aufgrund des niedrigen Wasserdrucks in den subglazialen Kanälen. Die beobachteten Erscheinungen am Grund des Gletschers entsprechen weitgehend nicht den Annahmen, die in den bestehenden Theorien des Gleitens angenommen werden.

\section{INTRODUCTION}

The overall flow of temperate glaciers is influenced strongly by processes taking place at or near the bottom. The ice-bedrock interface plays an important role in the mechanism of basal sliding, which is usually thought to account for about half of the total flow velocity observed at the glacier surface (Sharp, I954; Kamb and LaChapelle, I964; Paterson, I969, p. 77, 1970). Although a number of theoretical discussions of the sliding phenomena have been given (Weertman, 1957, I964, I97 I Lliboutry, 1959, I968; Nye, I969, I970; Kamb, 1970; Budd, I975; Morland, 1976) there have been few measurements of basal sliding velocities in glaciers, and even fewer direct observations of the actual sliding process taking place. Existing observations of basal sliding are confined to what could be seen at the head of tunnels excavated in glaciers (Klebelsberg, I 948-49, Bd. I, p. I43; Haefeli, I 95 I ; McCall, I952; Kamb and LaChapelle, 1964, 1968) or in natural subglacial cavities (Carol, I947; Souchez and others, 1973; Vivian and Bocquet, 1973; McKenzie and Paterson, 1975). These observations have necessarily been restricted to the shallower, more easily accessible parts of glaciers; the deeper parts, representing most of the basal portions of typical valley glaciers, have not been reached for observations of this type.

Some direct measurements of basal sliding velocity have been made in the tunnel experiments cited. Sliding velocities at the bottom of the deeper parts of some typical valley glaciers have been obtained indirectly, by combining measurements of surface velocity with the tilting of bore holes thought to penetrate to the glacier bed (see, for example, Savage and Paterson, 1963; Kamb and Shreve, r966; Raymond, r97 I). This indirect approach has two serious disadvantages: I. In bore holes drilled by the usual thermal method, there is no assurance that the bed is actually reached at the bottom of the hole, because rock debris or even a small amount of mud in the ice will stop the drill prematurely; hence the velocity determined at the bottom of the bore hole does not necessarily represent the actual sliding velocity at the base of the ice. (The recently reported measurement of sliding velocity by radio-echo sounding (Doake, 1975) is subject to the same disadvantage, since it depends on radio reflection from internal ice structures whose proximity to the bed is not definitely known.) 2. The accuracy and convenience of the measurements is generally not great enough to allow a determination of basal sliding velocity on a daily or even weekly basis, and all determinations up to now have been year-long averages; hence they necessarily have missed any shorter-term variations in sliding velocity, such as those that might be responsible for the difference between summertime and wintertime flow velocities of glaciers.

We report here the results of a method that gets around the difficulties stated, allowing us to observe and measure the sliding as seen in a bore hole reaching the glacier bottom, and to do so on a day-to-day basis. The observed conditions at the glacier bed during sliding are described, and the directly-measured sliding rates are given. The conditions are found to be rather different from those visualized in theoretical discussions. The directly measured sliding velocities do not agree well with those obtained by the indirect method as normally practiced. With special care, however, the two methods can be reconciled. 


\section{Field Setting}

In an area on Blue Glacier, Mt Olympus, Washington (lat. $47^{\circ} 4^{8^{\prime}} \mathrm{N}$., long. $123^{\circ} 4^{2^{\prime} \mathrm{W}}$.), shown in Figure 1,16 bore holes were drilled to the bottom of the ice, or almost to the bottom. The pattern of the bore-hole array, shown at an cnlarged scale in Figure $\mathrm{Ib}$, was designed to sample the bottom conditions across a sizable width of the ice stream of interest. The particular small area studied was chosen because previous detailed bore-hole deformation and
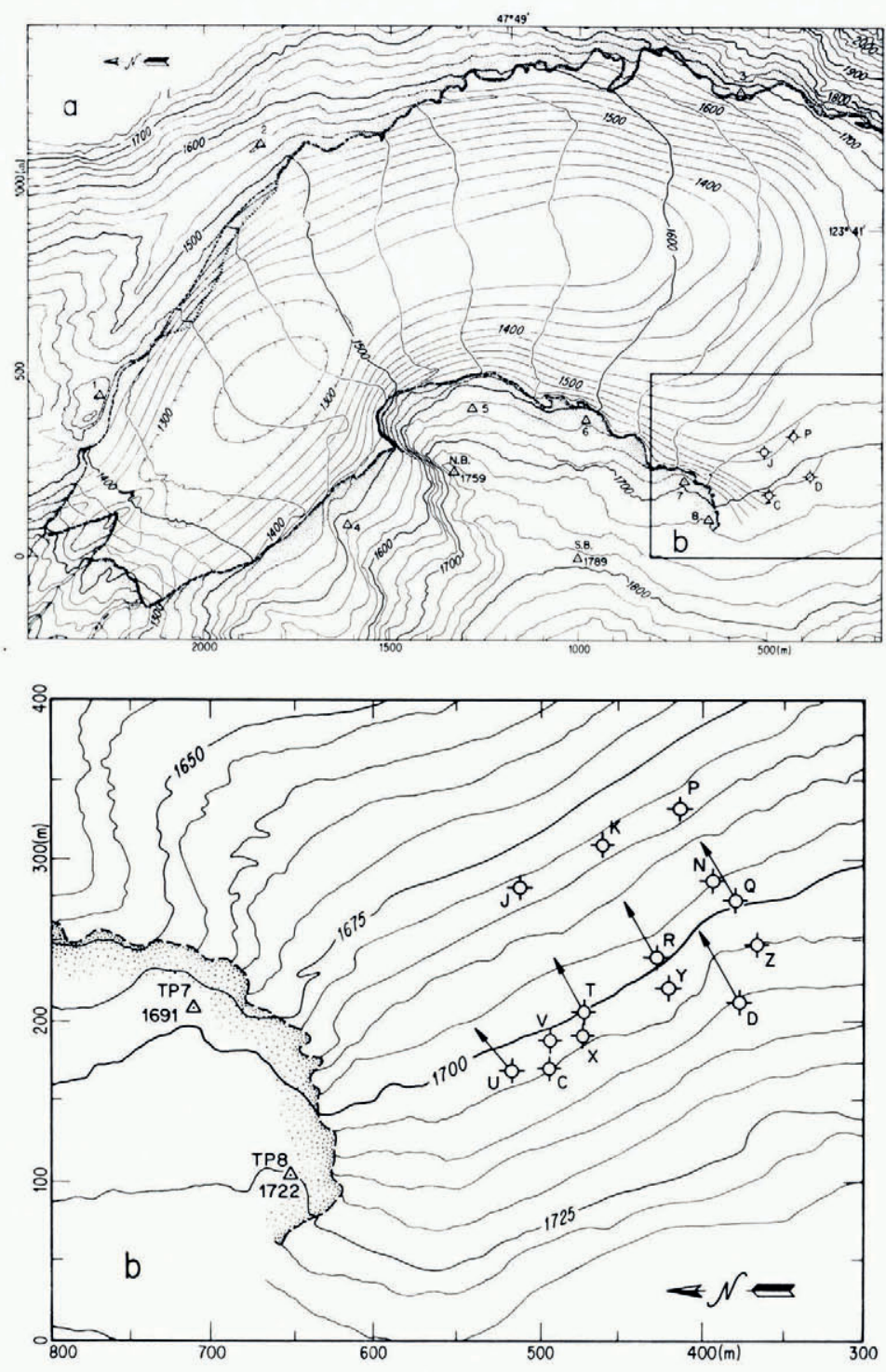

Fig. 1. Location of bore holes in Blue Glacier.

(a) Map of lower part of glacier, showing surface and bed topography, from Meier and others (1974, fig. I).

(b) Enlarged map of bore-hole study area, showing initial positions (circles) of bore holes discussed in paper and of four nearby earlier bore holes $(\mathcal{J}, K, P, \mathcal{N})$. Contour interval is $25 \mathrm{~m}$ in $(a), 5 \mathrm{~m}$ on ice surface in $(b)$. Meter scales at margins indicate scale of maps. Arrows show selected surface velocities measured during the study period and scaled to represent yearly motion. 
core-sampling studies in this area (Kamb and Shreve, I963[a], [b], I966) provide general information on the ice thickness, ice structure at depth, and flow velocity at depth, including the sliding velocity as determined by the indirect method based on bore-hole deformation. By comparison with other parts of Blue Glacier, exclusive of ice falls, the surface slope of the particular ice stream studied is relatively high (average $12.5^{\circ}$ ), so that high shear stresses are encountered at relatively shallow depths; although the ice thickness is modest (about $120 \mathrm{~m}$ in the area studied), flow velocities are reasonably high: about $15 \mathrm{~cm} / \mathrm{d}$ at the surface and about $6 \mathrm{~cm} / \mathrm{d}$ near the bed as inferred from deformation measurements in thermally drilled bore holes (Kamb and Shreve, r 966 ). The modest depth to the bed facilitated the field operations, many of which were being tried out for the first time in this work. The relationship of the area studied to the overall flow pattern, structure, and areal mass budget of Blue Glacier can be ascertained by reference to the earlier studies of LaChapelle (1959), Allen and others (1960), and Meier and others (1974). The work reported here was carried out during the summers of 1969 , 1970, and 1976 .

The bore holes were located at sites designated by the letters shown in Figure I. Basic data for these bore holes are compiled in Table I.

TABLE I. Bore-Hole charagteristics AND PHOTOGRAPHIC OBSERVATIONS

\begin{tabular}{|c|c|c|c|c|c|c|c|c|c|}
\hline I & 2 & Thick & $\begin{array}{l}4 \\
\text { zess of bas }\end{array}$ & al debris & $\begin{array}{c}6 \\
\text { zones }\end{array}$ & 7 & 8 & 9 & Io \\
\hline $\begin{array}{l}\text { Drilling } \\
\text { commenced }\end{array}$ & $\begin{array}{l}\text { Bore } \\
\text { hole }\end{array}$ & $\begin{array}{l}\text { Total } \\
\text { depth } \\
\mathrm{m}\end{array}$ & $\begin{array}{l}\text { Light to } \\
\text { moderate } \\
\text { debris } \\
\mathrm{m}\end{array}$ & $\begin{array}{l}\text { Heavy } \\
\text { debris } \\
\mathrm{m}\end{array}$ & $\begin{array}{l}\text { Basal } \\
\text { gap } \\
\mathrm{cm}\end{array}$ & $\begin{array}{l}\text { Sliding } \\
\text { motion } \\
\text { observed }\end{array}$ & $\begin{array}{c}\text { Number } \\
\text { of } \\
\text { photographs }\end{array}$ & $\begin{array}{c}\text { Period of } \\
\text { observation } \\
\text { (inclusive dates) }\end{array}$ & Remarks \\
\hline 3.July 1969 & Q & $12 \mathrm{I}$ & $2-3$ & ? & ? & no & IO & $\begin{array}{l}\text { 22 July } 1969 \\
\text { 22 July } 1969\end{array}$ & $\begin{array}{l}\text { Bed not } \\
\text { reached } \\
\text { Only I } \\
\text { bottom } \\
\text { photo- } \\
\text { graph, poor }\end{array}$ \\
\hline I4July i 969 & $\mathrm{R}$ & I I 4 & $2-4$ & ? & ? & no & I 4 & $\begin{array}{l}\text { 15July I } 969 \\
\text { I } 7 \text { July I } 969\end{array}$ & $\begin{array}{l}\text { Bed not } \\
\text { reached } \\
\text { No bottom } \\
\text { photo- } \\
\text { graphs }\end{array}$ \\
\hline 9.July 1969 & $\mathrm{~T}$ & 120 & 4 & 0.3 & I & yes & $5^{\circ}$ & $\begin{array}{l}\text { 23 July r } 969 \\
\text { I } 2 \text { September } 1969\end{array}$ & $\begin{array}{l}\text { Ice ledge } \\
\text { covered bed }\end{array}$ \\
\hline r 7 July r 969 & $\mathrm{U}$ & I 24 & O.I & o. I & $\sim 5^{\circ}$ & no & 2 & $\begin{array}{l}2 \text { I July r } 969 \\
2 \text { I July i } 969\end{array}$ & $\begin{array}{l}\text { Bottomed in } \\
\text { subglacial } \\
\text { stream } \\
\text { No bottom } \\
\text { photograph }\end{array}$ \\
\hline 28 July r 969 & V & I I9 & 0.3 & 0.3 & $2-6$ & yes & I 24 & $\begin{array}{l}\text { 17 August 1969 } \\
17 \text { September } 1969\end{array}$ & $\begin{array}{l}\text { Good sliding } \\
\text { record }\end{array}$ \\
\hline 23June 1970 & $\mathrm{X}$ & I 22.6 & $0 . \mathrm{I}$ & o. I & $1-3$ & yes & I 53 & $\begin{array}{l}6 \text { July I } 970 \\
\text { I5 September } 1970\end{array}$ & $\begin{array}{l}\text { Good sliding } \\
\text { record }\end{array}$ \\
\hline 22 July 1970 & $\mathrm{Y}$ & I 25.9 & I6 & 0.3 & o & yes & 66 & $\begin{array}{l}\text { I } 7 \text { August I } 970 \\
\text { I } 3 \text { September I } 970\end{array}$ & $\begin{array}{l}\text { Sliding } \\
\text { without } \\
\text { basal gap }\end{array}$ \\
\hline 7 July i 970 & Z & I 21.1 & 6.5 & 0.3 & $?$ & no & I4 & $\begin{array}{l}\text { 27. July } 1970 \\
8 \text { August } 1970\end{array}$ & $\begin{array}{l}\text { Bed maybe } \\
\text { not } \\
\text { reached }\end{array}$ \\
\hline 7 August 1976 & $\mathrm{C}$ & 132.2 & 0.2 & 0.2 & $\sim_{\mathrm{IO}}$ & yes & I I I & $\begin{array}{l}\text { I6 August }{ }_{1976} \\
5 \text { September }{ }_{1976}\end{array}$ & $\begin{array}{l}\text { Very little } \\
\text { sliding }\end{array}$ \\
\hline${ }_{13}$ August ${ }_{1976}$ & $\mathrm{D}$ & 132 & 7.6 & ? & ? & no & o & - & $\begin{array}{l}\text { Not com- } \\
\text { pleted to } \\
\text { bed }\end{array}$ \\
\hline
\end{tabular}




\section{Drilling to the glacier bed}

The holes were bored mainly by standard electrothermal methods, using a $5^{\mathrm{I}} \mathrm{mm}$ diameter hotpoint (Shreve and Sharp, 1970). Near the bottom in most of the holes, a premonitory decrease in drilling rate at constant power input, by a factor of about 2 or 3 , preceded by about $\mathrm{I} \mathrm{m}$ the almost complete cessation of drill penetration. The indicated $\approx \mathrm{I} \mathrm{m}$ zone of dirt-containing ice is doubtless the one observed in previous core sampling (Kamb and Shreve, I963[a]). Bore-hole photography (next section) showed, however, that the glacier bed had not been reached at the bottom of this zone.

In most of the bore holes, significant further progress of up to ro $\mathrm{m}$ was achievable with the thermal drill by bailing debris from the bottom of the hole at appropriate intervals. Bailing was done in 1969 with a stiff-bristled brush dipped in axle grease; in 1970 and 1976 a piston-type sand pump, with flap valve modified for greater retentivity, was utilized (Harrison and Kamb, I976). By suspending the drill from a device that reported each millimeter of forward advance of the drill, it was determined when the progress of thermal drilling had stopped completely.

Beyond this point, further drilling was done with a cable tool. The tool used in 1969 was a sharpened steel wrecking bar $2.5 \mathrm{~cm}$ in diameter and $1.5 \mathrm{~m}$ long. In 1970 and 1976 the much more effective combination of a standard $5 \mathrm{~cm}$-diameter cable-tool bit and drill stem, weighing $27 \mathrm{~kg}$, was used (Harrison and Kamb, I 976). The stem was raised and dropped with the help of a standard cat-head, driven by an electric or gasoline motor, with power output of about 375 or $2000 \mathrm{~W}$, respectively. Typically, drilling was carried out without interruption for Io to $30 \mathrm{~min}$, involving some $25^{0}$ to $\mathrm{I}$ ooo strokes of the bit, and was followed by 3 to 6 bailing hauls with the sand pump. The cable-tool drill penetrated clean ice at a rate of $\approx 1 \mathrm{~m} / \mathrm{h}$. In the debris-laden basal ice, the penetration rate was much less, and highly erratic, the erratic penetration being caused probably by varying sizes and quantities of rock clasts encountered in the ice. After advancing at the reduced and erratic rate for a fraction of a meter to several meters, the drill always reached a depth beyond which further advance was for practical purposes impossible. Prolonged drilling at this depth yielded additional rock debris for the bailer, but resulted in little or no detectable drill advance. This depth was taken to represent the base of the glacier, an interpretation confirmed by bore-hole photography (Section 5). Complications in this interpretation are discussed later.

The main difficulty experienced in cable-tool drilling was a tendency for the cable tool to stick at the bottom of some of the holes, especially in hole Z. The sticking was probably caused by a wedging of the cable tool among boulders protruding from the walls of hole in the debris-bearing ice near the bottom. This difficulty, which becomes more severe as the bore hole deforms, caused us to abandon the drilling of hole $\mathrm{Z}$ before the glacier bed was definitely reached. It could probably be ameliorated by using larger, heavier jars than were available.

\section{Methods of observation}

\section{(a) Bore-hole photography}

Photographs of the bottom of each completed bore hole were made with a bore-hole camera, whose construction and mode of operation are described elsewhere (Harrison and Kamb, r973, hereafter cited as "H \& K"). To eliminate camera motion, which tends to occur when the camera is freely suspended, a stabilizer, consisting of a $40 \mathrm{~cm}$-long cylindrical plastic brush of such a diameter $(75 \mathrm{~mm})$ as to bind lightly in the bore hole, was attached above the camera in 1976 .

For studying conditions and motions at the glacier bed, photographs taken vertically downward, from distances of 4 to $70 \mathrm{~cm}$ above the bottom, were used. Features of the debrisladen ice above the bed were observed in photographs taken horizontally at various heights 
JOURNAL OF GLACIOLOGY
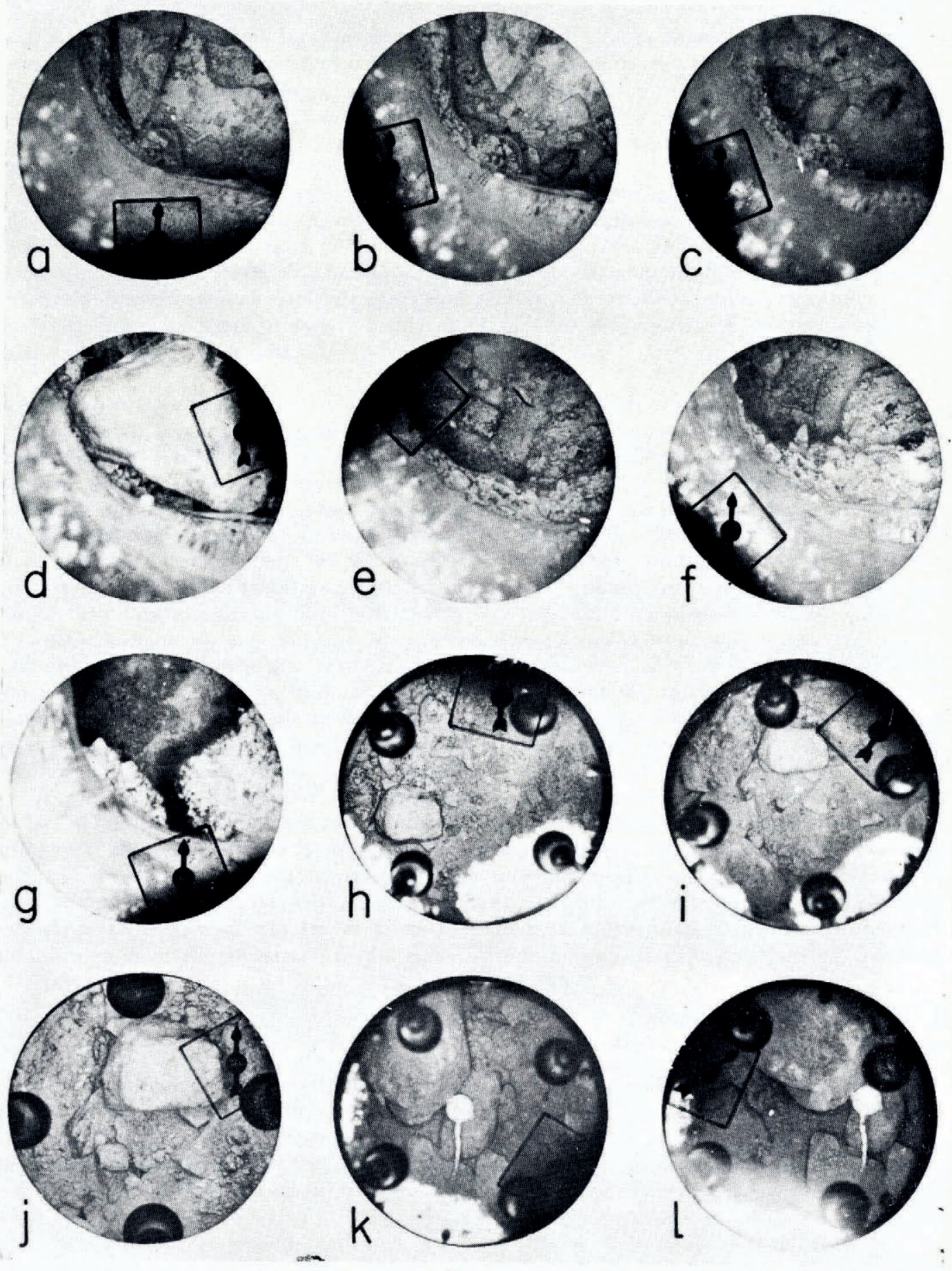
above the bottom. A selection of photographs of these types is shown in Figures 2-6; additional examples are given in $\mathrm{H} \& \mathrm{~K}$. The total number of photographs taken in each bore hole is listed in Table I. The scale for each photograph, determined by the methods discussed in $\mathrm{H} \& \mathrm{~K}$, is indicated in the figure captions by givin $\%$ the actual distance that corresponds, at the level of the bottom of the bore hole, or (for side-looking photographs) at the bore hole wall, to the full diameter of each circular image. This distance is given after the symbol $\varnothing$ in each caption. The white plastic ball visible in some photographs has a diameter of $9.5 \mathrm{~mm}$. The photographs are shown in a consistent orientation, with up (for views looking horizontally) or magnetic south (for views looking vertically downward) toward the top of the page. The orientation is referenced to a compass needle in the camera, or, if this is absent, to features in the bore-hole wall whose orientation was determined in other photographs in which the compass needle was used. The compass arrow points toward magnetic south in the photographs, because the compass needle lies immediately below the film in the camera and the image of the external scene is therefore inverted relative to it. (The magnetic declination is $23^{\circ} \mathrm{E}$; true north lies $23^{\circ}$ counterclockwise from the dircction opposite the compass arrow.) The black circular dot in some of the photographs is the shadow of the steel ball in the optional inclinometer unit $(\mathrm{H} \& \mathrm{~K}, \mathrm{p} . \mathrm{I} 3 \mathrm{I})$. The captions give the original photograph number of each photograph, as a matter of record and for reference to the original logs. Photographs mentioned in the text but not reproduced in the figures (to conserve space) are cited by their original photograph numbers.

In bore holes T, V, X, Y, and C, photographs of the bottom were gencrally taken at least once a day over a period of one to two months. To keep the bore holes open for passage of the camera during this period, the holes were reamed at least once a week with conical thermal drills of maximum diameter 62 or $71 \mathrm{~mm}$. For water-free holes, the need for reaming is due

Fig. 2. Photographs of the bottom of bore hole $V$. For each photograph, the following caption gives: original photograph number for reference), date, time, and, following the symbs $\varnothing$, scale of the photograph in terms of diameter of the circular field

(a) 1o. 93, 18 August $1969,16.05 \mathrm{~h}, \varnothing 86 \mathrm{~mm}$. The ice wall of the bore hole fills the lower left half of the picture. The ice is separated from the bed by several $\mathrm{cm}$, as indicated by the shadow along the boundary. The lighter areas of the bed are silt in patches among the rock fragments.

(b) Io. 99,19 August $1969,18.20 \mathrm{~h}, \varnothing 80 \mathrm{~mm}$. Same as (a) but taken one day later. Motion of the ice with respect to the bed $(I .1 \mathrm{~cm} / \mathrm{d})$ is evident by comparison of $(a)$ and $(b)$. On left at the base of the bore-hole wall is a thin layer of debrisladen ice, forming a projecting ledge separated from the bed by $4+2 \mathrm{~cm}$.

(c) Vo. 10I, 21 Al'g:'st $1969,9.55 \mathrm{~h}, \varnothing 82 \mathrm{~mm}$. Further motion has occurred, with appearance of new stones from beneath bore-hole wall.

(d) Vo. 107, 22 August $1959,12.20 \mathrm{~h}, \varnothing 72 \mathrm{~mm}$. A rounded cobble of uncertain origin now fills most of the picture, and prevents sliding re!-city meas trenents. It remained in this position until 25 August, when we pushed it out of the way wth a small cable t: $o^{\prime}$.

(e) . Vo. 115, 25 August $1969,18.45 \mathrm{~h}, \varnothing 77 \mathrm{~mm}$. The ledge of debris-laden ice seen in (a)-(c) has been partly removed, piobably by tile cable to 1 l used to push away the cobble in $(d)$. New debris-laten ice, apparent!y attached both to the bottom of the glacier and the bed, has become visible on the right.

(f) . . 1 119,25 August $1969,15.50 \mathrm{~h}, \varnothing 89 \mathrm{~mm}$. The configuration of the new debris-laden ice has changed considerably in less than a d'y, ant covers half of the originally visible ted. A pointed rock near the center of the photograph projects into the hole froin a mass of ice that has formed below the level of the ice sole as it was in $(e)$.

(g) Vo. $137, I$ September $1969,12.55 \mathrm{~h}, \varnothing 86 \mathrm{~mm}$. Some of the new de'sris-laden ice h 7 s been melted away by the hotpoint. The melting has opened a gap between the bed and the remaining debris-laden ice, wlich now forms two ledges.

(h) . Vo. $14^{8}, 5$ September $1969,10.00 \mathrm{~h}, \varnothing_{102} \mathrm{~mm}$. The four circular objecls near the periphery of the photograph are lamp reflector assemblies in the $24 \mathrm{~cm}$ viewing tube used. The two bright a eas in the lo.cer part of the picture are the ledges seen in $(g)$.

(i) Va. ${ }_{54}, 6$ September $1969,10.30 \mathrm{~h}, \varnothing 93 \mathrm{~mm}$. The motion in the day since $(h)$ is obvious. The velccity is now $2.7 \mathrm{~cm} / \mathrm{d}$, more than twice that obseried earlier. The compass needle here has stuck in a false orientstion because of moisture in the camera.

(i) No. ${ }^{155}, 6$ September $1969,13.20 \mathrm{~h}, \varnothing 59 \mathrm{~mm}$. Tetails of the debris-strewn bed are seen in this close-up view. In relation to (i), a small pebble has appeared in the lower left part of the picture.

(k) No. 159,7 September $1969,10.15 \mathrm{~h}, \varnothing 96 \mathrm{~mm}$. The diameter of the white ball is $9.5 \mathrm{~mm}$.

(l) No. I6I, 8 September $1969,10.5^{\circ} \mathrm{h}, \varnothing .92 \mathrm{~mm}$. Photographs $(k)$ and $(l)$ are rotated $45^{\circ}$ clockwise relative to $(\mathrm{g})-(\mathrm{i})$, in order that they can be viewed as a stereo pair. A sliding motion of $2.9 \mathrm{~cm} / \mathrm{d}$ is approximately parallel to the line connecting the pair. 

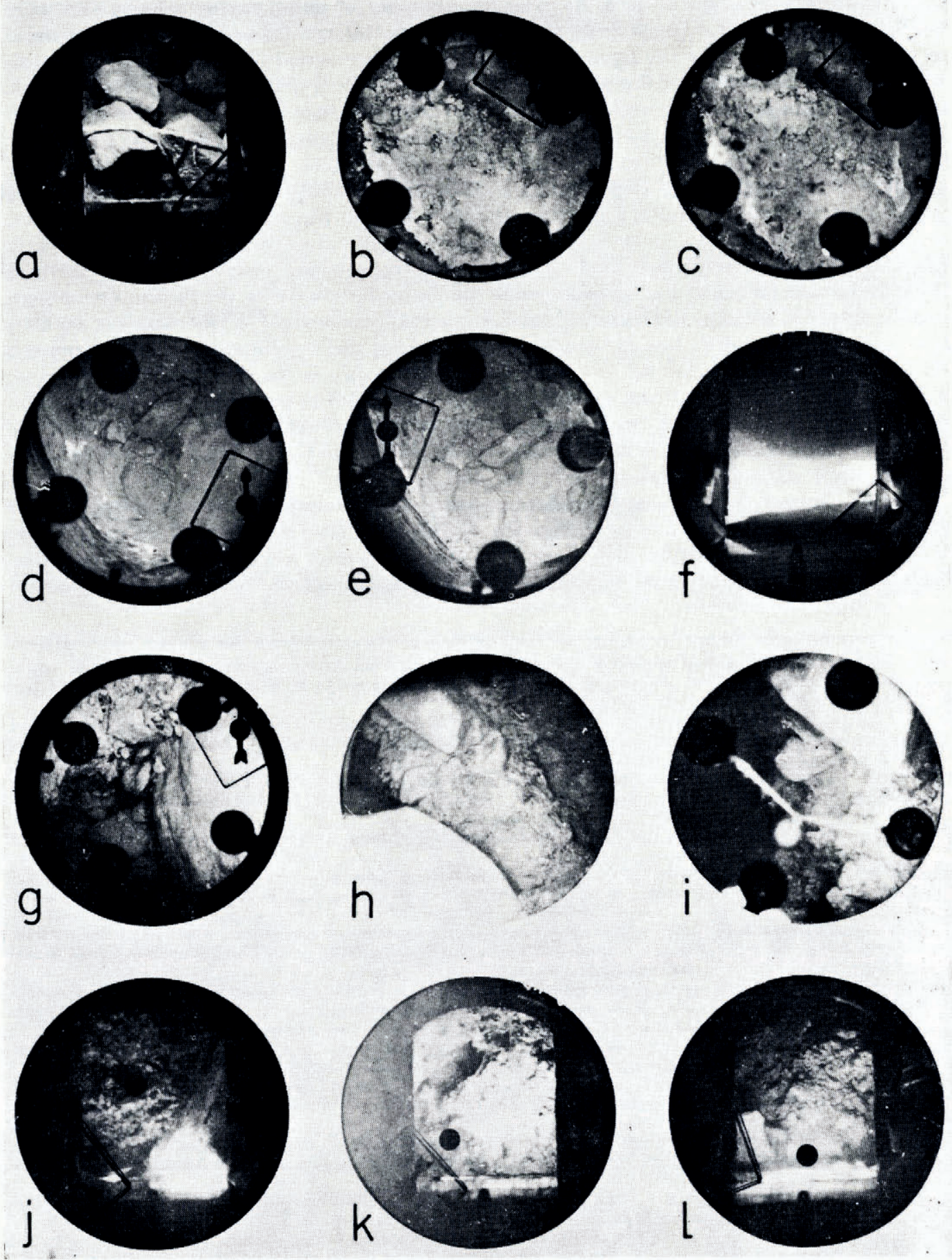

Fig. 3 . 
simply to bore-hole contraction by ice flow. Closure also occurs for water-filled holes in temperate ice, owing to the refreezing process discussed by Harrison (1972). Because of changes that took place at the bottom of some of the holes during the period of observation it was necessary to redrill with the cable tool occasionally and in some instances repeatedly.

The main obstacle to bore-hole photography was turbidity due to suspended glacial flour. At the bottom of the bore holes, the water was initially almost opaque, especially after cabletool drilling. Procedures used for overcoming this difficulty by air-lift pumping in 1969 and 1970 are described in $\mathrm{H} \& \mathrm{~K}$ (p. I3 I). In 1976 a much more powerful (5 ooo W) pump, operating at the surface, was used to pump clean water to the bottom of the bore hole through $38 \mathrm{~mm}$ diameter mining hose. The pumping rate achievable was $6.5 \mathrm{l} / \mathrm{s}$ at a pressure of $3.8 \mathrm{~atm}$. A volume of water equal to four times the entire bore-hole volume could be pumped to the bottom of the hole in $5 \mathrm{~min}$, flushing out the hole thoroughly. This flushing was successful in removing turbidity temporarily from the bottom of the bore hole, so that photographs could be made immediately thereafter. Turbidity commonly returned later, particularly after renewed cable-tool drilling, so that repeated flushing was necessary. Once the water in a bore hole had begun to leak out from the bottom (see Section $5 \mathrm{~g}$ ) it was generally unnecessary to flush the hole to achieve clear conditions.

\section{b) Indirect methods}

The performance of the cable-tool drill and the contents of the bailer provide information about conditions at and near the glacier bed, as discussed in Section $5 \mathrm{~b}$. A penetrometer, consisting of a sharpened steel rod (diameter $\mathrm{I} \mathrm{cm}$ ) on which a hollow cylindrical weight (attached to the drilling cable) slides with limited travel, was used in 1976 to ascertain the penetrability of material at the bed. The $27 \mathrm{~kg}$ weight can be dropped a distance of $75 \mathrm{~cm}$ before striking the steel rod to drive it downward; the sharpened end of the rod, free to penetrate into the bed material, is $30 \mathrm{~cm}$ long.

The sliding velocities measured directly by bore-hole photography in bore holes X and C were checked by indirect determinations of the standard type based on bore-hole inclinometry and surface surveying.

Fig. 3. Photographs of bore holes $V, T$, and $X$.

(a) V, No. 158, II September 1969, 15.50 h, $\varnothing 72 \mathrm{~mm}$. Side-looking picture taken with bottom of camera touching the bed. It shows ice-free debris extending at least $5 \mathrm{~cm}$ above bed. Viewing direction is toward 90 'clock in relation to Figure $2 k$, and string is the one visible in Figure $2 k-l$.

(b) T, No. I49, 5 September 1969, 10.50 h, $\varnothing 86 \mathrm{~mm}$. View of bore-hole bottom. Most of the bottom consists of debris-laden ice ledge attached to the base of the glacier. A small, slightly lower area at top center is part of the actual bed.

(c) T, No. 151, 5 September 1969, $15.20 \mathrm{~h}, \varnothing 80 \mathrm{~mm}$. Photograph taken $4.5 \mathrm{~h}$ after $(b)$. Apparent motion of the bed in relation to the ice ledge, from comparison with $(b)$, amounts to roughly $1 \mathrm{~cm} / d$.

(d) $T$, No. 172, 10 September $1969,17.10 \mathrm{~h}, \varnothing 86 \mathrm{~mm}$. Bottom has changed greatly from that in (c). Bright spots at left and lower center may be reflections from bare ice surfaces.

(e) $T$, No. ${ }_{17} 6,11$ September $1969,11.55 \mathrm{~h}, \varnothing 86 \mathrm{~mm}$. The motion between $(d)$ and $(e)$ involves jumbling and tilting of clasts, plus an apparently retrograde translation northward.

(f) T, No. ${ }_{184}, 12$ September $1969,18.05 \mathrm{~h}, \varnothing 72 \mathrm{~mm}$. Side view, showing that bottom of the camera has sunk into mud.

g) $X, B-36,{ }_{16} .7 u l y ~ 1970,17.30 \mathrm{~h}, \varnothing 102 \mathrm{~mm}$. Close-up view of part of bottom before start of sequence in Figure 4. Large, subrounded rock on right is later visible in Figure $4 a$. Debris at top left appears cemented by ice because it has not collapsed down into hole at left center. Subsequent photographs $(B-37, B-39, B-44$, Fig. 2a) show that collapse gradually occurs, hence the cementation must be weak.

(h) $X, B-75,4$ August $1970,17.30 \mathrm{~h}, \varnothing_{1} 60 \mathrm{~mm}$. Close-up of bottom on day following Figure $4 \mathrm{~g}$. Steep debris bank above hole at left center again suggests ice cementation of debris. Progressive collapse of this bank is seen in the sequence of Figures $4 f, 3^{h}, 3 i, 4 g, 4^{h}$. Cobble at lower left is imbedded in ice of bore-hole wall and is also seen in Figure 4 .

(i) X, B-81, 6 August $1970,15.10 \mathrm{~h}, \varnothing .93 \mathrm{~mm}$. Closer detail in field of $(h)$, after further collapse of debris bank. Ball suspended on string is $11.1 \mathrm{~mm}$ in diameter.

(i) $X, A-67,26$ August $1970,16.15 \mathrm{~h}, \varnothing 72 \mathrm{~mm}$. Side-looking picture. Lower edge is $21 \mathrm{~cm}$ above bottom of hole. Shows lightly debris-laden ice on left, and, at lower right, part of the cobble seen in bore-hole wall in $(h)$.

(k) $X, A-40,12$ August $1970,15.15 \mathrm{~h}, \varnothing 72 \mathrm{~mm}$. Side view, with lower edge $1 \mathrm{~cm}$ above bed. Shows upward transition from heavily to lightly debris-laden ice.

(l) $X, A-57,15$ August $1970,14.27 \mathrm{~h}, \varnothing 72 \mathrm{~mm}$. Side view of heavily debris-laden ice at base of glacier. Bottom of camera was set $3 \mathrm{~cm}$ above bottom of bore hole, but bed appears to be visible at bottom edge of photograph. 
JOURNAL OF GLAGIOLOGY
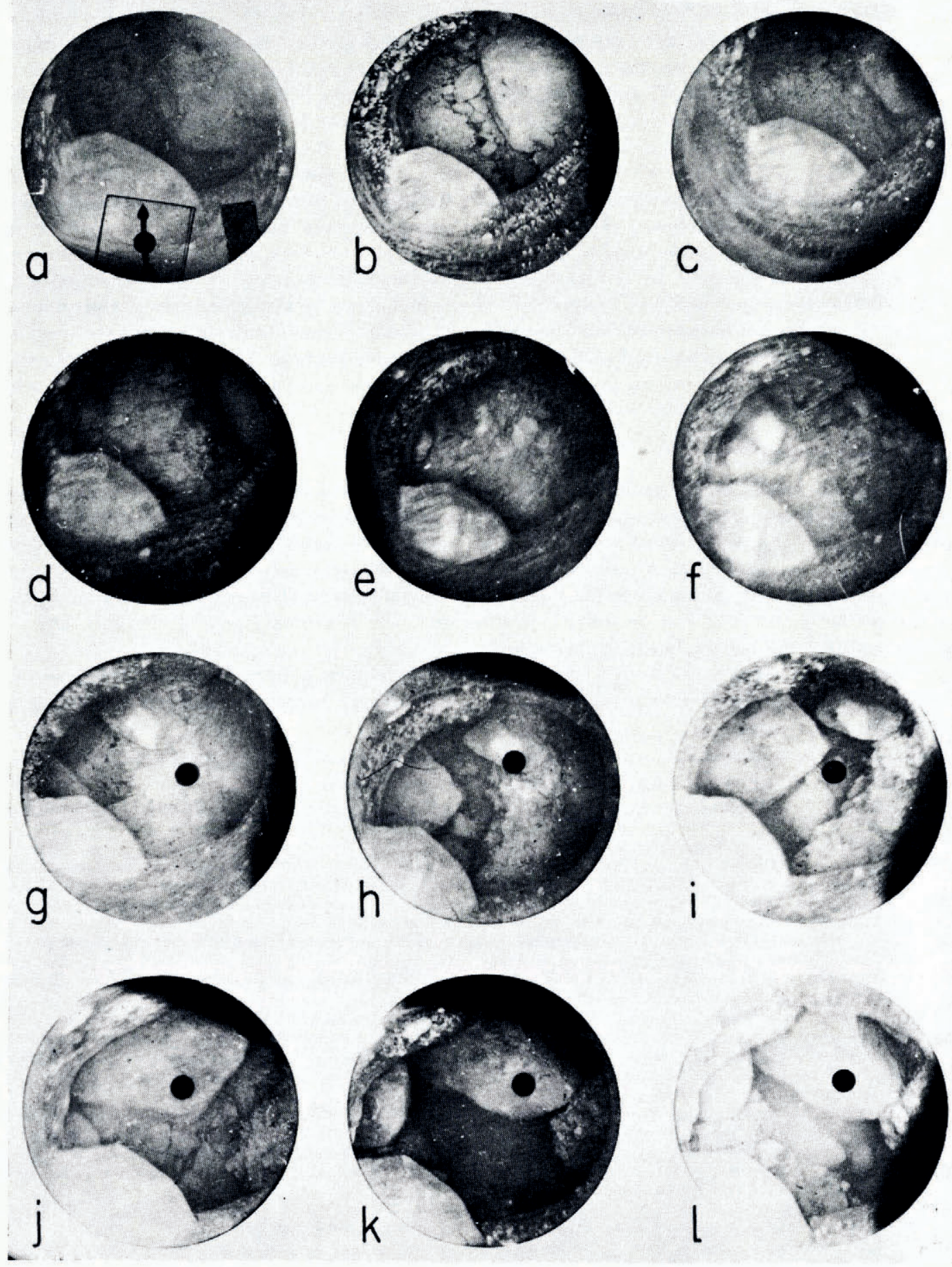

Fig. 4. 


\section{Conditions observed at the glacier bed}

\section{(a) Motion}

Evidence that the glacier bed was reached in holes T, V, X, Y, and C is lateral motion of the bottom with respect to the bore-hole walls, seen in successive photographs taken at intervals of a few hours to a week. The photograph sequences in Figs $2 \mathrm{a}-\mathrm{c}, 2 \mathrm{~h}-\mathrm{i}, 2 \mathrm{k}-\mathrm{l}$, $5 \mathrm{e}-\mathrm{f}$, and $5 \mathrm{~g}-\mathrm{j}$ show such motions. The direction of motion of the ice with respect to the bottom, determined with the help of a compass needle in the camera, is consistently within about $20^{\circ}$ of the slope of the glacier surface and the direction of ice flow at the surface. We interpret this translational motion as due to the sliding of the glacier over its bed. The quantitative features of the sliding motion are considered in Section 6. In the discussion below we refer to the "entrance side" of a bore hole as the side from which bed materials enter the bottom of the hole in the sliding process, and the "exit side" as the side toward which they disappear; these are respectively the down-stream and up-stream sides in relation to the flow of the glacier.

\section{(b) Bed materials and configuration}

The glacier bed revealed in our photographs invariably consists of rock debris. In some examples, angular fragments 0.4 to $4 \mathrm{~cm}$ in size appear to be set in a pale-toned muddy or sandy matrix (Figs 2a, b, h; $3 \mathrm{~d}, \mathrm{e}, \mathrm{f} ; 4 \mathrm{e}, \mathrm{f}$ ). In others, the bottom consists of generally larger fragments (up to at least $10 \mathrm{~cm}$, the approximate diameter of the bore hole at the bottom), with little or no matrix (Figs $3 \mathrm{a}, \mathrm{g} ; 4 \mathrm{~b}, 1 ; 6 \mathrm{~h}, \mathrm{i}$; H \& K, fig. 6a). Clasts of graywacke, argillite, and vein quartz are recognizable in the photographs as well as the bailer hauls; these lithologies are typical of the bedrock of the area. Clasts larger than about $\mathrm{I} \mathrm{cm}$ in size generally show some indications of rounding or faceting, probably by glacier abrasion, and some are well rounded (Fig. 2d); smaller clasts are generally angular.

Fig. 4. Sequence of photographs of bottom of bore hole X. Cobble embedded in the ice of the bore-hole wall at lower left serves as a reference mark for the motion of the glacier relative to its bed. The ice of the bore-hole wall ends with a clearly visible edge, below which is a gap between ice and subsole drift. Large clasts and finer debris pass across the bore-hole bottom from lower left to upper right as the glacier slides over its bed.

(a) $B-47, I_{3}$ July $1970,10.10 h, \varnothing_{142} \mathrm{~mm}$. Large sub-rounded clast in upper right was seen earlier in Figure $3 g$.

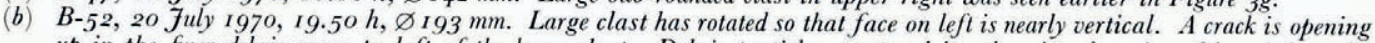
up in the finer debris mass to left of the large clast. Debris particles scattered in otherwise clear ice of bore-hole walls are clearly visible.

(c) B-55, 21 July $1970,16.35 \mathrm{~h}, \varnothing 177 \mathrm{~mm}$. Crack has opened further and partly collapsed as large clast moves out toward top right.

(d) B-58, 25 July 1970, 18.30 h, $\varnothing 182 \mathrm{~mm}$. Crack has widened greatly and become a gap between debris bank and large clast. Opening of this gap indicates that debris mass is being carried along by glacier to some extent, while clast remains behind. Motion between $(a)$ and $(d)$ corresponds to $0.7 \mathrm{~cm} / d$.

(e) $B-67,29$ July $1970,17.3^{\circ} \mathrm{h}, \varnothing_{13} \mathrm{H}_{\mathrm{mm}}$. Clast visible in $(a)-(d)$ has disappeared and gap has widened further. A smaller rock is just entering hole from left. Debris bank has moved toward upper right, showing that it is not solidly attached to the glacier.

(f) B-73, 3 August 1970, 12.50 $\mathrm{h}, \varnothing_{184} \mathrm{~mm}$. Light cable-tool drilling has produced the depressed circular area at right.

g) $B-83,8$ August $1970,14 \cdot 30 \mathrm{~h}, \varnothing_{1} 32 \mathrm{~mm}$. From the left has appeared a natural cavity in the subsole drift, the edge of which is seen in greater detail in Figure 3 h and $i$. Motion between this and the previous photograph amounts to $0.6 \mathrm{~cm} / \mathrm{d}$.

(h) $B-87,10$ August $1970,18.45 \mathrm{~h}, \varnothing 170 \mathrm{~mm}$. The cavity is now seen to be a gap between the debris bank on the right and a large angular rock that has entered from the left. This gap narrows between $(g)$ and $(h)$, showing that the debris mass is being partially dragged along by the glacier.

(i) B-go, I3 August I970, II.04 h, $\varnothing 153 \mathrm{~mm}$. Motion of the large rock corresponds to $1.4 \mathrm{~cm} / \mathrm{d}$. It has caught up with the smaller rock at upper right, which has come loose from the debris bank, perhaps by hanging up against the bore-hole wall.

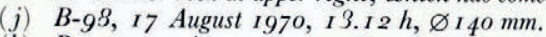

(k) $B-135,24$ August $1970,16.35 \mathrm{~h}, \varnothing 14^{0} \mathrm{~mm}$. The large rock has become caught under the ice at top center and has begun to roll.

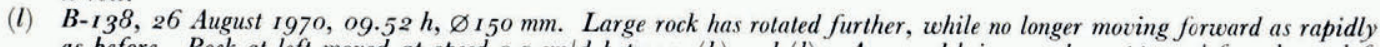
as before. Rock at left moved at speed $0.9 \mathrm{~cm} / \mathrm{d}$ between $(k)$ and $(l)$. A new debris mass has appeared from lower left and has almost caught up with large rock at top right. 
JOURNAL OF GLAGIOLOGY
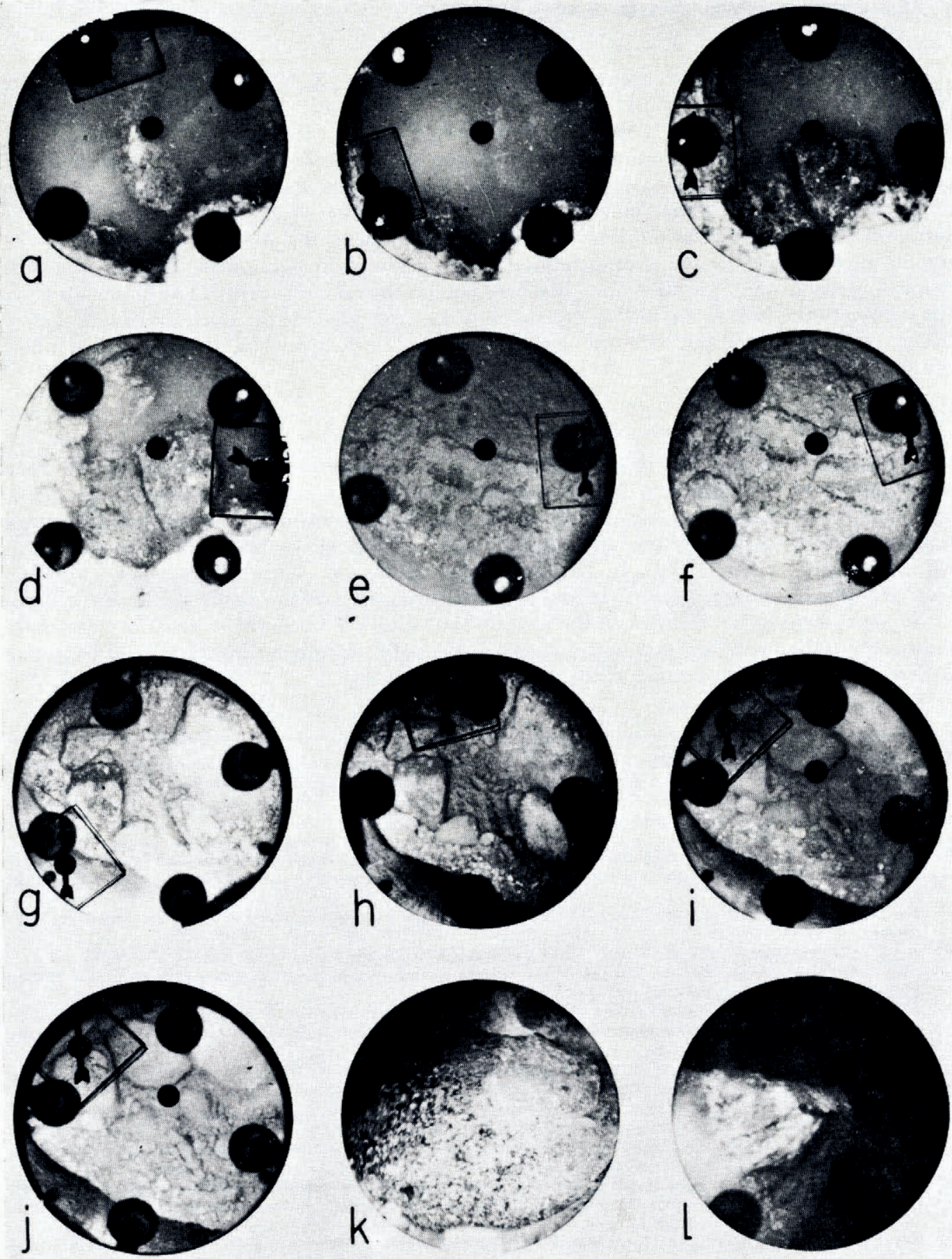

Fig. 5. 
In no case do we observe any definite bedrock at the bottom of our bore holes. This finding is contrary to our original expectations, which were based on the abundance of massive, abraded and striated bedrock outcrops at the margin of the glacier near the area studied, and below the terminus. In an effort to expose any bedrock concealed at shallow depth beneath the visible debris-strewn surface, we used repeated and forceful bailing to suck up the loose debris from the bottom, both with and without alternate cable-tool drilling to penetrate the debris and break up the larger fragments. The bailer loads decreased progressively, from full loads $\left(\approx 600 \mathrm{~cm}^{3}\right)$ at the start to only a few $\mathrm{cm}^{3}$ toward the end. This gives the impression that the drilling and bailing is able to clean up the bottom of the hole, but in no case were we able to reach a point when no rock debris at all was recovered by the bailer. In spite of vigorous bailing, repeated as much as six times, subsequent photography always revealed a debris-strewn surface without any definite bedrock.

Figure $6 \mathrm{e}$ and $\mathrm{f}$ show our best example of what might be a bedrock surface underlying rock debris. The surface does not appear smoothed or striated by glacial abrasion as we might expect, but its uneven, fractured appearance might be the result of damage produced by earlier cable-tool drilling. However, the previous history of the bore hole argues for interpreting at most only part of the surface visible in Figure 6e as bedrock - specifically, the slightly raised part along the east (left) edge: this is a part of the same surface seen more extensively in Figure 6c, where deeper parts of it are exposed, showing that the material to the west (right) in Figure 6e is in fact rock debris covering the formerly deeper area. If the rock surface rising toward the north-east (lower left) in Figure 6c is bedrock rather than part of a large clast, then the bedrock surface must be much rougher and more irregular than typical glaciated bedrock outcrops are. The roughness is probably not due to drilling damage, because the part of the surface that remains visible in Figure $6 \mathrm{e}$ was not affected by the extensive drilling done between Figure $6 \mathrm{~d}$ and e.

In the attempt to reveal bedrock, an important difficulty experienced in 1969 and 1970 was the long time (often several days) required to restore the turbid bottom water to a clarity adequate for photography, after the churning action of the drill or bailer had rolled it up (H \& K, p. I3I). During this long time, the sliding motion could have displaced a freshly cleaned surface out of sight, fresh debris could have fallen from the bore-hole walls, and fines

Fig. 5. Bottom photographs of bore holes $Y$ and $Z$.

(a) $Y, B-I I 4,2 I$ August $1970,11.23 \mathrm{~h}, \varnothing 83 \mathrm{~mm}$. Low cloud of turbidity hugging bottom of hole partially obscures graywacke fragment at center.

(b) $Y, B-117,21$ August 1970, $16.56 \mathrm{~h}, \varnothing 33 \mathrm{~mm}$. Turbidity cloud has risen, obscuring almost completely the graywacke clast, which however remains faintly visible, and has moved to the right from its position in $(a)$.

(c) $Y, B-122,22$ August $1970,14.46 \mathrm{~h}, \varnothing 82 \mathrm{~mm}$. Cloud level has dropped and new clasts have appeared.

(d) $Y, B-125,22$ August $1970,19.13 \mathrm{~h}, \varnothing 82 \mathrm{~mm}$. Cloud has dropped further and almost disappeared, at top. Rectangular clast has moved at about I cm/d since $(c)$. Compass needle stuck in erroneous orientation.

(e) $\quad$, B-I54, I September $1970,16.30 \mathrm{~h}, \varnothing 83 \mathrm{~mm}$. Character of bottom has changed markedly since (d). It now appears to consist of ice (dark) almost completely coated with fine rock debris.

(f) $\Upsilon_{1}, B-156,2$ September $1970,13.00 \mathrm{~h}, \varnothing 83 \mathrm{~mm}$. Visibility of dark markings, interpreted as exposures of ice, is improved. Markings have moved southward (toward top), indicating some sliding motion.

(g) $Y, A-80,8$ September $1970,18.45 \mathrm{~h}, \varnothing 86 \mathrm{~mm}$. A debris-strewn bottom has reappeared.

(h) $Y, A-8 I, 9$ September $1.970,09.00 \mathrm{~h}, \varnothing 86 \mathrm{~mm}$. A slight southward motion (toward top) has occurred, and a new clast has appeared at lower right.

(i) $\quad \mathrm{r}, \mathrm{A}$-9o, Io September $1970,17.11 \mathrm{~h}, \varnothing 86 \mathrm{~mm}$. Further southward motion, amounting to $0.5 \mathrm{~cm} / \mathrm{d}$, has occurred. The new clast appears to have jumped south-eastward (toward upper left) to a position at top center.

(j) $\Upsilon$, A-gI, II September $1970,16.00 \mathrm{~h}, \varnothing 86 \mathrm{~mm}$. Further southward motion. No gap between bore-hole walls and bottom is visible in $(e)-(j)$.

(k) Z, A-I, 27 July $1970,15.22 \mathrm{~h}, \varnothing 143 \mathrm{~mm}$. Large rock at bottom of bore hole, appearing like bedrock except that its edge is visible toward top. Subsequent cable-tool drilling penetrated the rock and continued a further $60 \mathrm{~cm}$. Water was clear at level of rock, but turbid below.

(l) Z, A-34, 8 August $1970,17.03 \mathrm{~h}, \varnothing 88 \mathrm{~mm}$. Shows rock protuding from bore-hole wall $150 \mathrm{~cm}$ above bottom. This rock must have been intruded into the hole, because it blocked the hole to passage of the camera where earlier there was no obstruction. 
JOURNAL OF GLACIOLOGY
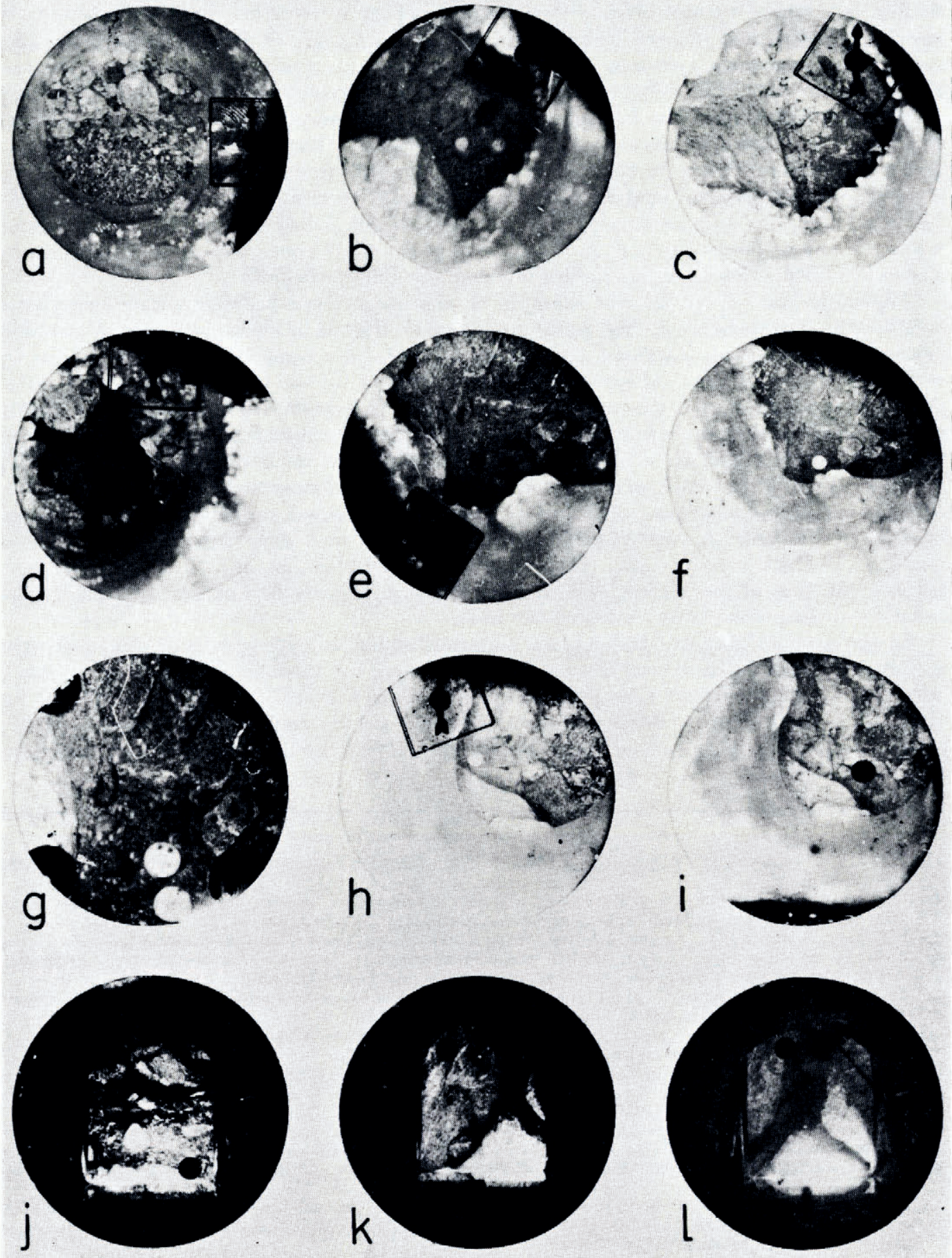

Fig. 6 . 
could have settled out from suspension. However, the flushing technique used in 1976 made it possible to take photographs within about two hours after the completion of bailing; also, the rapid loss of water from hole $\mathrm{C}$ after the first two weeks entirely eliminated the problem of water turbidity in that hole. Furthermore, the translational motion at the bottom of hole C was so small (see Section 6) that there was no possibility of displacement of a freshly cleaned surface out of sight by sliding. Yet the same failure to expose any definite bedrock was experienced, unless the rock surface seen in Figure $6 \mathrm{c}-\mathrm{e}$ is in fact bedrock.

A second difficulty confronting our effort to reveal bedrock is the fact that the typical graywacke (sandstone) bedrock is inherently somewhat difficult to distinguish photographically from disaggregated sand derived from graywacke. Under the best photographic resolution the distinction is unmistakable: the individual grains in loose sand are resolved with greater sharpness and contrast than the grains in sandstone, owing to the sharp fine shadows that border the loose sand grains; the distinction is enhanced if the sandstone surface has been smoothed by abrasion. For example, the north (lower) half of the bore hole bottom in Figure 6a shows sand, whereas the north-east (lower left) quarter in Figure 6c shows a graywacke surface (discussed above). Photographs A-89, A-92, A-I04, and A-I 5 show progressive covering of an initially clean graywacke surface (the top of a $6 \mathrm{~cm}$ clast) by a thin layer of sand that presumably settled out gradually from the bore hole. With poorer resolution, which often occurs because of technical problems, the distinction between rock surface and sand is less clear, and a number of our photographs present this problem to a greater or lesser extent. The most problematical example among the photographs in Figures $2-6$ is Figure $5 \mathrm{k}$; in this case, however, the surface is that of a large rock imbedded in the ice, as shown by the edge details seen toward the south (top) and by the subsequent drilling history (discussed later). In no case where this problem presents itself have we been able by subsequent photography to convince ourselves that we had seen a smooth bedrock surface; instead, it always appeared

Fig. 6. Photographs of bore hole $C$.

(a) B-I84, I6 August 1976, I7.02 h, Ø240 mm. Photograph was taken before cable-tool drilling. Water was already leaking rapidly from hole at bottom, so that there was no turbidity, and fines had been washed out of the subsole drift, leaving coarse sand and pebbles. There is no gap at the base of the bore-hole walls.

(b) B-194, 20 August 1976, $14.50 \mathrm{~h}, \varnothing 200 \mathrm{~mm}$. After cable-tool drilling and bailing, the base of the bore-hole walls has been undermined by excavation of subsole drift. A pair of rocks at left, attached to the base of the ice, appears to have been intruded rapidly into the hole since it would not have survived the immediately previous cable-tool drilling.

(c) B-196, 20 August $1976,18.20 \mathrm{~h}, \varnothing 200 \mathrm{~mm}$. Bailing with sandpump has knocked away the intruded pair of rocks and has removed the two white plastic balls visible on the bottom in $(b)$. The large, somewhat smooth rock on the left remains visible through the sequence $(b)-(g)$.

(d) B-198, 21 August 1976, 13.25 h, Ø240 mm. Hole contraction and intrusion of rocks at base of ice is highly evident by comparison with $(c)$.

(e) A-I 25, 28 August $1976,11.35 \mathrm{~h}, \varnothing_{1} 66 \mathrm{~mm}$. Movement southward of the distinctive light marking on the rock surface at left center, from $(c)$ to $(e)$, corresponds to a sliding motion of $0.3 \mathrm{~cm} / d$, with some uncertainty due to possible modification of the bore-hole walls by extensive cable-tool drilling during this period.

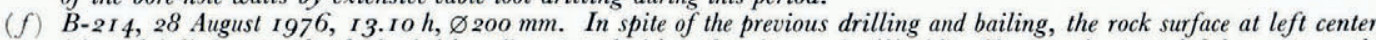
$(e)$ and $(f)$ is more deeply buried by adjacent rock debris than it was in $(b)-(d)$. Sharp rock at top left has apparently been intruded. White veinlets (probably quartz) visible on bottom in $(e)$ and $(f)$ suggest an underlying rock surface, but this does not seem confirmed in $(\mathrm{g})$.

(g) B-2I6, 28 August $1976,18.45 \mathrm{~h}, \varnothing_{74} \mathrm{~mm}$. Detail of field seen in $(f)$, showing loose rocks and detail of veinlets exposed on rough rock surfaces. Edge of large rock surface is at left.

(h) $B-235,4$ September $1976, I_{1.15} h, \varnothing_{190} \mathrm{~mm}$. After extensive cable-tool drilling and bailing subsequent to ( $\mathrm{g}$ ), the bottom of the hole is completely altered but the depth of the bottom appears unchanged. Large rock protruding into hole from under the ice at lower left appears different from rock seen in $(b)-(g)$.

(i) $B-239,4$ September $1976,13.50 \mathrm{~h}, \varnothing_{190} \mathrm{~mm}$. In the short time since $(h)$, a rounded pebble has appeared in upper center, just left of the black dot. Position of dot shows that hole is tilted $13^{\circ}$ from vertical.

(j) $B-23^{8}, 4$ September $1976,13.05 \mathrm{~h}, \varnothing 80 \mathrm{~mm}$. Side view looking south-west at bottom. Shows subsole drift. Larger rocks appear to overlie finer debris.

(k) $B-242,4$ September $1976,17.00 \mathrm{~h}, \varnothing 80 \mathrm{~mm}$. Side view looking north-east, taken $7 \mathrm{~cm}$ above bottom. Large rocks are probably those seen at lower left in $(h)$ and $(i)$.

(l) $B-245,5$ September $1976,14.30 \mathrm{~h}, \varnothing 80 \mathrm{~mm}$. Side view looking north-east, with camera set $10 \mathrm{~cm}$ above bottom. The rocks are the same ones seen in $(k)$, but they have shifted somewhat relative to one another. 
that we had seen a smooth patch of loose sand. An unmistakable feature of rock is the presence of light (quartz) veinlets, such as those seen in some of the clasts in Figure $6 \mathrm{~g}, \mathrm{k}$, i, and 1 . Such features were never seen in the sand surfaces in question.

Although some of the loose debris seen at the bottom has probably fallen from the borehole walls, most of it was originally present on the glacier bed either within or outside the area exposed in the bottoms of the holes. This is evident from successive photographs in holes $\mathrm{V}$ and $\mathrm{X}$, where the debris appeared from beneath the base of the bore-hole wall on one side of the hole and disappeared intact on the other side (Figs 2 and 4 ). In hole C, the debriscontaining ice above the base, being only $20 \mathrm{~cm}$ thick and only lightly debris-laden, could have furnished only a small fraction of the volume of debris removed by bailing from the bottom of the hole (see below). We believe that most of the debris seen at the bottom of holes $\mathrm{T}$ and $\mathrm{Y}$ (Figs 3 and 5 ) was likewise present originally at the base of the glacier, although this is not proven from direct evidence in these holes.

Since our bore holes reveal rock debris rather than bedrock at the base of the glacier, it is important to estimate the thickness of this debris and the depth to bedrock beneath the base of the ice. For this we use three lines of evidence:

I. Performance of the cable-tool drill: with prolonged drilling, the maximum distance penetrated below the base of the ice (as revealed by bore-hole photography) was about $20 \mathrm{~cm}$, and the drilling rate at this depth became negligibly slow. For example, drilling at the bottom of hole $\mathrm{C}$ produced an advance of about $\mathrm{I} 5$ to $20 \mathrm{~cm}$ during the first hour or so, and subsequent drilling, totalling some $5 \mathrm{~h}$, produced a negligible advance beyond this depth. The negligible rate of drill advance is evidence that the drill is encountering bedrock at this depth. In tests carried out at the surface we find that a penetration rate of the order of $2 \mathrm{~cm}$ per minute is achieved when the drill is cutting moraine or loose debris, provided the hole is bailed frequently; when cutting bedrock the penetration rate is very low, $\mathrm{I}$ to $2 \mathrm{~cm}$ per hour. If the debris is loose and the hole caves, the rate of drill advance is progressively slowed as the hole widens, and becomes limited by the rate of bailing, but from our experience and the capacity of our bailer we judge that if we had been drilling in rock debris of unlimited depth we would have achieved a penetration substantially deeper than $15^{-20} \mathrm{~cm}$ after drilling for a total of $6 \mathrm{~h}$, with frequent bailing. A direct indication of the ease of drill penetration in rock debris is given by Photograph B-72 and Figure $4 \mathrm{f}$, which shows the visible effect of 10 min of light drilling (by hand) with a $2.5 \mathrm{~cm}$ star drill (considerably lighter than the cable tool). A circular depression several centimeters deep was cut into the debris by this operation; it can be seen by comparing the west (right) half of Figure $4 \mathrm{f}$ with the corresponding part of Figure 4 e. We expect that substantially greater penetration would be achieved in the same time by the heavy, cat-head-powered cable tool. The fact that in hole $\mathrm{C}$ no such penetration was achieved between Figure $6 \mathrm{~d}$ and e by $30 \mathrm{~min}$ of cable-tool drilling followed by sand-pump bailing, or between Figure $6 \mathrm{~g}$ and $\mathrm{h}$ by two $30 \mathrm{~min}$ cable-tool-drilling operations, each followed by several bailer hauls, indicates to us that solid rock lies immediately below the debris-strewn surface seen in these photographs.

2. Recovery of debris by bailing: when drilling and bailing were done alternateiy, the volume of the successive bailer loads decreased progressively (though more slowly than when bailing was done without alternate drilling), and the grain size of the bailed debris decreased progressively also. This is what would be expected if, at the greatest depth reached, the drill bit encounters bedrock: the amount of available debris should become progressively limited, and the grain size should decrease as the drill smashes the available clasts against the underlying bedrock. Conversely, if bedrock were not reached, the volume and grain size of the recovered debris would not change markedly or progressively, whether or not the hole caves.

3. Penetrometer tests: starting from the bottom of bore hole $\mathrm{C}$ as seen in Figure $6 \mathrm{a}$, the penetrometer (described in Section 4) could be driven down about $6 \mathrm{~cm}$ into the rock debris. After cable-tool drilling and bailing had deepened the hole to the extent seen in Figure 6b, 
the penetrometer was no longer able to penetrate an appreciable distance, more than I or $2 \mathrm{~cm}$, into the bottom. The same result was obtained for the bottom seen in Figure 6e. In each of these tests the driving weight was dropped 30 times onto the penetrometer bit from a height of $70 \mathrm{~cm}$, and the tests were repeated several times with the bit raised and relowered onto the bottom so as to test the penetrability in different spots. Tests of the penetrometer at the surface show that penetrations of $30 \mathrm{~cm}$ (full penetration) are readily achieved in both loose and compacted granular materials containing abundant pebbles up to $5 \mathrm{~cm}$ in size. Two or three strokes of the driving weight are sufficient for such penetration. The penetrometer is temporarily halted by 5 to $10 \mathrm{~cm}$ clasts, but with repeated impacts of the driving weight the granular material becomes loosened, the penetrometer bit works its way around or between the obstructing clasts, and penetration resumes. Large enough clasts will obviously stop the penetrometer and be indistinguishable from bedrock, but we find that in typical moraine at the surface, such clasts are rare. Hence we conclude that with high probability, the impenetrability of the bore-hole bottom in hole $\mathrm{C}$ implies that bedrock is present at a depth of at most a few centimeters beneath the bottom surface seen in Figure $6 \mathrm{~b}$ and e.

From the above evidence we conclude that, in the area studied, the glacier is not underlain by a substantial thickness of rock debris, which would essentially constitute a ground moraine in place under the ice. Such a ground moraine also seems unlikely because the relatively steep slope $\left(9^{\circ}-12^{\circ}\right)$ and fast flow of the ice in the area studied favor subglacial erosion rather than deposition. Instead, the bed consists of bedrock overlain by a thin layer of rock debris, some 5 to $20 \mathrm{~cm}$ thick, intervening between the solid rock and the base of the ice. We will call this debris the active subsole drift, for reasons to be developed presently.

In bore-hole $\mathrm{X}$ the subsole drift exhibited distinct cohesion as shown by its ability to stand in vertical bands under water (Figs $3 \mathrm{~h}, \mathrm{i} ; 4 \mathrm{~d}, \mathrm{e}, \mathrm{h}, \mathrm{i}, \mathrm{k}$ ). (Photograph A-6o shows a side view of this cohesive material.) The drift in the other holes appears loose and cohesionless (Figs $\left.2 \mathrm{i} ; 3^{\mathrm{a}}, \mathrm{e} ; 5 \mathrm{~h} ; 6 \mathrm{a}, \mathrm{i}\right)$, but the particular conditions of sliding that led to formation of vertical debris banks in hole $\mathrm{X}$ were not duplicated in the other holes, hence it is possible that the gravel in those holes had some cohesion also. The evidence for caving of debris in hole C, discussed in Section $5 \mathrm{c}$, indicates little or no cohesion in this material. Some of the debris banks in hole $\mathrm{X}$, such as the one created by drilling (in Fig. $4 \mathrm{f}$ ) and the one in the center of Figure $3^{\mathrm{h}}$ (seen in more detail in Fig. $3 \mathrm{~h}$, i), collapsed gradually with time, again indicating small cohesion. The cohesion shown in hole $\mathrm{X}$ indicates that some cementation of the debris has occurred. The general looseness of the subsole debris suggested by the photographs implies that the cement is weak or present in only small amounts. Some cohesion of the subsole gravel can be attributed to its clay content: the clay-containing compacted till in nearby lateral moraines shows a similar ability to stand at least temporarily in steep or vertical banks, even under water. Ice, if present as a cement in the subsole gravel, occupies only a small fraction of the water-saturated interstitial void space. The typical subsole gravel contrasts visibly with the debris-laden ice ledges that are sometimes found at or very near the level of the sole, as described in Section $5 \mathrm{e}$ : these have a visible ice matrix and substantial strength. From the above considerations we conclude that the subsole gravel is primarily ice-free. Locally within the subsole gravel there do occur regions of partial or possibly complete ice cementation related to the basal ice ledges, as discussed in Section $5 \mathrm{e}$.

\section{(c) Contact or gap between ice and subsole gravel}

In so far as the subsole gravel is ice-free, the boundary between it and the overlying glacier is the surface above which a continuous mass of ice, usually containing included rock debris, extends upward into the body of the glacier. This surface we call the glacier sole. In the borehole photographs taken looking vertically downward we recognize this surface as a level where the bore-hole walls appear to come to an end as traced downward. In holes V (Fig. 2), 
$\mathrm{X}$ (Fig. 4), C (Fig. 6), and T at an early stage (Photograph No. I 32 ) there is visible a sharp, well-defined level of this kind, below which there appears to be a gap between the sole and the subsole gravel. Later in hole T (Fig. 3b-f), and in hole Y (Fig. $5^{\mathrm{a}-\mathrm{j}}$ ), the bore-hole walls disappear into the gravel without an apparent gap; in this case we cannot demonstrate visibly from the photographs that the sole has been reached, and must rely on the evidence from drilling and the observation of sliding motion.

Where there is no apparent gap, it is evident that the ice must be in intimate contact with the subsole drift. A side view of this situation in hole $\mathrm{Y}$ is seen in Photograph A-95, showing ice that is lightly debris-laden (except in the lowermost $2 \mathrm{~cm}$, where it is clear) resting on fine debris.

Where an apparent gap is visible, it can be interpreted in two distinct ways: I. No gap actually existed originally, but the process of cable-tool drilling into the subsole drift produced an enlarged hole there through caving of the loose debris, which undermined the base of the ice and produced a local gap around the periphery of the hole; this was the situation in hole C, as explained in a later paragraph. 2. An actual gap existed originally between the base of the ice and the top of the subsole drift prior to hole drilling; this was probably the situation at bore holes $\mathrm{V}$ and $\mathrm{X}$.

The evidence for a true gap at the bottom of holes $\mathrm{V}$ and $\mathrm{X}$ is the emergence of rock debris from under the bore-hole walls and its disappearance under the walls by simple translatory motion with little disturbance such as would necessarily be caused by contact with the overlying ice (Figs 2 and 4). For hole $\mathrm{X}$ there is also confirmatory evidence from bore-hole deformation measurements (Section 6). A lateral view at the bottom of hole X, Photograph A-42, shows the gap but, because of the limited range of the camera lights, does not reveal how far away from the bore hole the gap extends. The visible width of the gap in this photograph is $\mathrm{I} .5$ to $3 \mathrm{~cm}$. A $4 \mathrm{~cm}$ gap width in hole $\mathrm{V}$ was estimated by $\mathrm{H} \& \mathrm{~K}$ (p. $\mathrm{I}_{33}$ ). The gap is narrow enough that the larger clasts, after passing across the hole, sometimes hang up on the "exit side" (see Section $5 \mathrm{f}$ ). It is possible that a local gap was excavated initially as a result of hole enlargement by cable-tool drilling in holes $\mathrm{V}$ and $\mathrm{X}$, and that such a gap could for a time have permitted the visible debris to move in simple translatory motion without disturbance; but the large total sliding motion $(\approx 50 \mathrm{~cm})$ in these holes would have carried away the initially enlarged hole and would have eliminated the gap if it had been only a local feature.

The gap represents the occurrence of ice-bed separation or subglacial "cavitation" (Kamb, 1970 , p. 720). In contrast to the narrow separation gap seen in holes $\mathrm{V}$ and $\mathrm{X}$, a cavity $\mathrm{I}$ to $2 \mathrm{~m}$ high was revealed by photography in a hole that penetrated a subglacial cavern in the ice fall $0.5 \mathrm{~km}$ up-stream from the present study area (H \& K, fig. 7).

Because of the long time (about $20 \mathrm{~d}$ ) required for initial water clarification in holes $\mathrm{V}$ and $\mathrm{X}$, it is possible that the gap developed only after the noles were drilled, as a result of cavitation caused by pressurization of the base of the ice under the pressure of water standing in the hole (see Section $5 \mathrm{~g}$ ).

Hole enlargement by lateral caving of subsole gravel in hole $\mathrm{C}$ is demonstrated by consideration of the volume of rock debris removed by bailing from the hole. In aggregate this volume amounted to $3600 \mathrm{~cm}^{3}$. In a bore hole of average diameter $10 \mathrm{~cm}$ (estimated from Fig. 6b, f, and $\mathrm{h}$ and Photograph A-126), this volume represents a column of rock debris standing to a height of $45 \mathrm{~cm}$. The actual maximum depth of penetration of the hole in the subsole gravel is only 15 to $20 \mathrm{~cm}$, as measured in the course of drilling. (This depth is confirmed from Figure $6 \mathrm{k}$ and l, as follows: these pictures, taken with the base of the camera at an average height of $8 \mathrm{~cm}$ above the bottom of the hole, show loose rocks without ice up to a height of $13 \mathrm{~cm}$ above the bottom; from the compass needle we infer that the rocks seen in Figure $6 \mathrm{k}$ and $\mathrm{l}$ are the rocks seen in the north-east (lower left) part of the hole in Figure $6 \mathrm{~h}$, and from this we judge that the base of the ice (which was not captured in a horizontal 
photograph) lies no more than a few centimeters above the highest point seen in Figure $6 \mathrm{k}$ and 1.) Thus at least half of the debris removed from the hole must have come from outside the visible area of the bottom of the hole. (The amount of debris contributed from within the ice above the sole can be neglected because the thermal drill was able to penetrate essentially to the level of the sole before being stopped by rock debris.) We infer that a process of enlargement of the hole by caving of loose debris from its walls occurred and resulted in the apparent gap between ice and subsole drift seen in vertical views (Fig. 6b-i). That the enlarged outer part of the hole, hidden under the ice in vertical views, has appreciable volume is indicated by our occasional experience of finding one or more of the white plastic balls to have disappeared from sight only to reappear later or be recovered in later bailer hauls. Loose debris forming the caved walls of the hole can be seen in side views (Fig. 6j-l). Independent evidence for caving is the partial filling of the bottom of hole $\mathrm{C}$ that occurred between the taking of Figure $6 \mathrm{~d}$ and e, during a period when intensive cable-tool drilling and bailing was done: the deeper part of the large rock surface visible in the north-east (lower left) portion of Figure 6c and $\mathrm{d}$ is buried in Figure 6e. We infer that the pounding action of cable-tool drilling is able to shake down debris from the hole walls even when the bottom of the hole has essentially reached bedrock.

That there was no gap between ice and subsole drift in hole $\mathrm{C}$ is inferred from three pieces of evidence: (I) lateral views show debris rather than open space (however, a crucial view just below the level of the sole was not obtained); (2) bore-hole deformation measurements indicate that the ice is in contact with the bed (Section 6); (3) pressurization of the bed by water in the bore hole was low nearly from the beginning (Section $5 \mathrm{~g}$ ), hence pressureinduced cavitation is unlikely.

\section{(d) Basal zone of debris-laden ice}

The presence of rock debris in the ice immediately above the sole is shown by the slowing or cessation of thermal-drill penetration, by bailing, by bore-hole photography, and by recovery of ice cores containing debris (Kamb and Shreve, I963[a]). The debris ranges in size from large clasts to fine rock flour. Figures $4,5 \mathrm{k}, \mathrm{l}$, and $6 \mathrm{i}$ show vertical views of clasts imbedded in ice of the bore-hole walls. Parts of the large clast in Figure 4 are seen in side view on the upper left in Photograph A-42 and on the lower right in Figure $3 \mathrm{j}$. The central and left part of Figure $3 \mathrm{j}$ and the upper-right part of Photograph A-42 show the appearance in side view of ice laden with fine debris; the debris particles appear bright against a dark background of clear ice. Figures $2 \mathrm{a}-\mathrm{c}$ and 4 show such ice as viewed from above. In Figure $2 \mathrm{a}-\mathrm{c}$ it forms the rim at the bottom of the bore-hole wall on the east and north-east side (left and lower left). (An enlarged view of this material is shown on the lower left in H \& K (fig. 4).) In Figure 4 it is visible all around the lower part of the bore-hole walls, most clearly in Figure $4 \mathrm{~b}$ and $\mathrm{k}$. Some of the individual debris particles seen in these photographs are probably aggregates of fine rock flour, which, as found from ice cores (Kamb and Shreve, $1963[\mathrm{a}])$, tends to occur in lumps one to a few millimetres in size. These flour lumps are difficult to distinguish from sand grains except by very close inspection or by freeing the particles from the ice by melting. In side views under water near the bottom, the ice surface of the bore-hole wall is invisible, and the ice is made visible only by the debris lumps and air bubbles in it (Fig. 3a, j). The photographic distinction in side view between debris-laden ice (Fig. $3 \mathrm{a}, \mathrm{j}$ ) and subsole debris with little or no interstitial ice (Figs $3 \mathrm{k}, 1 ; 6 \mathrm{j} ; \mathrm{H} \& \mathrm{~K}$, fig. 6b) is somewhat subtle and becomes difficult as the debris content of the ice becomes large.

Estimates of the thickness of the basal debris zone are given in Table I, the zone being somewhat arbitrarily divided into an upper part with "light to moderate debris" content and a lower part with "heavy debris". These estimates are based on the experiences in drilling the bore holes. The top of the "light to moderate debris" zone is where appreciable slowing 
of thermal-drill penetration was detected, and this zone includes debris-laden ice that could be penetrated either by alternate thermal drilling and bailing or by cable-tool drilling with rapid penetration rate $(>c . \mathrm{I} \mathrm{m} / \mathrm{h})$. Material that slowed the cable-tool drilling rate to $\approx 10 \mathrm{~cm} / \mathrm{h}$ or less is called "heavy debris"; it includes both heavily debris-laden ice above the sole and the subsole drift, where reached. The zone of "heavy debris" was found to be $<c .0 .3 \mathrm{~m}$ thick; this is similar to the thickness of the subsole drift estimated from bore-hole photography and penetrometer tests. Hence we conclude that most of the zone of "heavy debris" is in fact the subsole drift. It follows that above the sole there is little if any basal ice so heavily loaded with rock debris that it impedes cable-tool drilling to an extent comparable to that caused by the subsole drift or that which fully debris-packed ice would. The zone of debris-laden basal ice is thus essentially equivalent to the material represented as "light to moderate debris" in Table I. This debris-laden ice zone is relatively thin $(c$. o. I to $0.3 \mathrm{~m}$ ) in the northern part of the area studied (from hole X northward) and thick (2 to $16 \mathrm{~m}$ ) in the southern part (hole $\mathrm{T}$ southward). Similar large lateral variations in thickness of the basal zone of dirty ice have been found by tunnel observations in the ice fall up-stream from the study area (Kamb and LaChapelle, I964, I968). This zone is more or less equivalent to the "basal ice layer" described by Vivian and Bocquet (1973, p. 443) from tunnel observations.

The basal zone at hole $\mathrm{Z}$ contained a large rock (Fig. $5 \mathrm{k}$ ) which reduced the cable-tool drilling rate to about $10 \mathrm{~cm} / \mathrm{h}$ and might have been erroneously interpreted as bedrock or heavy basal debris if the cable tool had not succeeded in drilling past this obstruction and penetrating rapidly another $35 \mathrm{~cm}$ before encountering the "heavy-debris" zone at the bottom. We were unable to use bore-hole photography to determine whether this "heavy debris" was subsole gravel or debris-packed ice.

Bore-hole photography provides a check on the thickness of the basal zone of debris-laden ice in hole X. Figure $3 \mathrm{j}$, a side view taken $21 \mathrm{~cm}$ above the bottom, and Photograph A-68, $24 \mathrm{~cm}$ above the bottom, show debris-laden ice, while Photograph A-69, $55 \mathrm{~cm}$ above the bottom, shows ice with a scattering of fine, bright specks that are probably air bubbles rather than rock particles. The bottom of the hole reached by the base of the camera was probably Io to $20 \mathrm{~cm}$ below the sole because of the basal gap and because a deep cavity, probably large enough for the camera to enter, had opened up in the subsole gravel at this time (Fig. $4 \mathrm{k}, \mathrm{l}$ ). (The wall of this cavity is seen in Photograph A-6o, taken at the bottom.) Hence the o. I m thickness of the basal debris-laden ice zone estimated from drilling (Table I) is roughly compatible with the height, bracketed in the range 0.2 to $0.5 \mathrm{~m}$, to which debris in the ice extends above the bore-hole bottom as indicated by bore-hole photography. It appears to us intuitively from Figure $4 \mathrm{~b}$ and similar photographs that the large clast in the north-east (lower left) side of the hole extends to a height greater than $10 \mathrm{~cm}$ above the sole, perhaps $20 \mathrm{~cm}$ above; this clast was probably not encountered in the original thermal drilling and probably became exposed by subsequent hole enlargement through reaming and cable-tool drilling.

A problem in determining by bore-hole photography the thickness of the basal debris layer is the difficulty of distinguishing photographically between fine debris particles and air bubbles. The distinction is clear when the hazy, mottled or banded appearance of irregularly bubbly or bubble-foliated ice is displayed (Photograph B-246; H \& K, fig. 8b). Comparison of side views taken near the bottom (as cited above) with side views at depths of about $50 \mathrm{~m}$ (Photograph Nos 1 7, 22, 58, and A-37) shows that the basal ice is much less bubbly than ice in the main mass of the glacier. This has been previously noted in ice cores (Kamb and Shreve, I $966[\mathrm{~b}]$ ) and in a tunnel up-stream from the study area (Kamb and LaChapelle, I967). Already at a height $2 \mathrm{~m}$ above the bottom in hole C (Photograph B-246) there is a marked increase in air content over that of the basal ice.

In none of our photographs, either vertical or horizontal, have we seen in the basal ice just above the sole any structural features indicative of a regelation layer, such as has been observed 
in tunnels (Kamb and LaChapelle, 1964, I968). The expected features are however, subtle, and could easily escape detection. In fact, no regelation layer was visible by direct visual inspection at the head of one branch of our 1967 tunnel in the Blue Glacier ice fall (Kamb and LaChapelle, I968), where the sliding velocity was $\mathrm{I} \mathrm{cm} / \mathrm{d}$ and the basal ice was air-free and debris-laden.

There is evidence suggesting that rock clasts in the basal ice zone near our bore holes were sometimes extruded from the bore-hole walls out into the bore holes. The evidence is that bore holes that were originally open and free to the passage of the camera, sand-pump bailer, and cable-tool sometimes later developed obstructions that caused one or more of these pieces of equipment to hang up when being lowered into the affected hole. In one such instance, in hole $\mathrm{Z}$, the later obstruction was photographed and proved to be a pointed rock projecting out into the bore hole (Fig. 5l). The obstructions could usually be removed with the cable tool, as would be expected if they were projecting rocks. Because the obstructions often developed rather suddenly and independently of our reaming operations, we think that the projecting rocks were in many cases actually extruded rather than merely becoming exposed by hole enlargement through reaming. Some projecting rocks such as the clast in the northeast (lower left) side of hole X (Fig. 4), were definitely not extruded and remained stably in place for weeks. The lack of extrusion of such clasts may be a consequence of the gap between sole and subsole drift, which freed the ice locally from the pressure of the ice overburden except to the extent supported by water pressure, which was high in hole X. Conversely, obstructions formed frequently in hole $\mathrm{C}$, where there was no gap and the water pressure in the hole was low. Expulsion of clasts from the sole of the Glacier d'Argentière has been reported by Vivian and Bocquet (1973, p. 443) and by Souchez and others (1973, fig. 4).

\section{(e) Basal ice ledges}

In hole $\mathrm{V}$ for a period of some ten days there were visible two ledge-like masses of debrisladen ice attached to the base of the bore-hole wall on the up-stream (north) side at the level of the sole, and projecting out over the bore-hole bottom at an appreciable height above the bed, so that they cast shadows on the bed. They are seen in Figure 2g, Photograph No. I40, Figure $2 \mathrm{~h}$ and $\mathrm{i}$, Figure $2 \mathrm{k}$ and $\mathrm{l}(\mathrm{H} \& \mathrm{~K}$, fig. $3 \mathrm{a}, \mathrm{b})$, and Photographs Nos 163 , I66, I7 1 , and $\mathrm{I} 75$. In the course of sliding, the subsole drift appeared without disturbance from beneath these ledges, showing that they were not mechanically supported by the bed, as is implied also by the presence of the gap between them and the bed. Their self-supported configuration indicates substantial strength, and we infer that they consisted of solid ice heavily loaded with rock debris. The debris gives them a generally bright appearance, which is enhanced by their closeness to the camera lights. Individual rock fragments can be seen to be set in a dark (clear) ice matrix in Figure $2 \mathrm{~g}$ and Photograph No. 140 , forming a distinctive lumpy texture.

The sequence of happenings in Figure 2 shows that these ledges developed in the following way. At an early stage, in Figure $2 \mathrm{a}-\mathrm{c}$, a rim of debris-laden ice was present at the base of the bore-hole wall on the north-west (lower left) side of the hole, in the form of a narrow ledge sticking out a centimeter or so from the wall. It was probably shaped into this form by earlier thermal and cable-tool drilling at the bottom of the hole. After three days' obstructed visibility due to the clast seen in Figure $2 \mathrm{~d}$, this original ledge is found to have been extended westward (to the right) around the base of the wall (Fig. 2e), and it is now seen to connect (or nearly so) to an apron of material similar in appearance that slopes down southward to join the bed (in the upper right part of Figure 2e). All of this material has the distinctive lumpy texture due to its content of debris. Apparently much of the ice in the apron and the lower part of the ledge is coated with light-colored mud (rock flour), so that ice is visible only in the few spots where this coating of mud has fallen away. The exposed ice appears as small, very 
dark patches. As time progresses to Figure $2 \mathrm{f}$, the apron moves southward (up) with the general motion of the rocks on the bed to the left, and the ledge is carried with it though at a slower rate, so that both the apron and the ledge expand as they are extended southward. In Figure $2 f$ a light-colored spine, probably a sharp rock, appears, apparently pushed out from below and behind. By the time of Photograph No. I 22 the rock has dropped away; the extension and expansion of the apron and ledge continue. In this expansion many of the fine details in these objects change but some distinctive features such as dark ice patches remain recognizable. What is evidently happening in this sequence of photographs is that a mass of debris-laden ice that is in contact with, and to a large extent stuck to, the subsole drift is being carried across the bottom of the bore hole by the sliding motion. This mass also adheres to the debris-laden ice that forms the "ledge" above it, and pulls or shears this out across the bore hole. The expansion of ledge and apron thus represents the localized mechanical deformation of a debris-laden ice mass that is coupled simultaneously to the sliding sole and the fixed bed; it does not represent growth by freezing of ice. By the time of Photograph No. 129, the apron and ledge (which have now merged into a single feature) have expanded in this way to cover a large part of the visible bottom of the hole; the bed is seen darkly only in the upper left. The apron-ledge combination appears to have become coated with additional rock particles and mud, so that its previously recognizable surface features are no longer discernible. At this point the thermal drill was lowered to the bottom of the hole and operated at nearly full power for $5 \mathrm{~min}$ in an effort to remove the ice ledge. The drill apparently bottomed in the southeastern (upper left) part of the hole, resting either on the subsole drift or on the southern part of the apron. As a result (Fig. 2g, h) the south-eastern part of the ledge and apron was melted away, leaving the northern part intact except for a fissure which now divided it into two pieces. Apparently the heat that was dissipated against the subsole drift spread to some extent laterally, severing the apron from the ledge and undermining the ledge by melting underneath, so that thereafter the two remnants of the ledge were no longer in contact with or coupled to the bed. The fissure actually did not appear until two days after the heating was done, showing that significant ablation of the ledge continued over an extended period; subsequent further ablation, causing widening of the fissure and retreat of the left-hand ledge, is visible in Photograph No. I 40. Other than this, the two ledges did not change appreciably during the $\mathrm{r} 2 \mathrm{~d}$ of observation following the heating.

The development of ice ledges in hole $\mathrm{V}$ is followed in detail in the above description because the photographs in this hole reveal clearly the occurrence of a process that also operated, in modified form, in three of the other holes, but that would be obscure there were it not for its graphic demonstration in hole V. At an early stage in hole $\mathrm{T}$ there was probably a gap between the ice and subsole drift. This is suggested by the rather gloomy and fuzzy views in Photographs Nos I 32 and I34, which show a shadow cast on the bore-hole floor by the ice rim above the gap; sliding motion is indicated by the appearance of a clast from under the ice in Photograph No. I 34 on the north side of the hole. By the time (five days later) when a really clear picture was obtained (Fig. 3 b), the gap at the base of the bore-hole wall had disappeared, but a small area of lower ground remained at the southern (upper) edge of the visible part of the bottom. Within this lower area a translational motion of about $\mathrm{I} \mathrm{cm} / \mathrm{d}$ was occurring in a southerly direction, indicating northward sliding, as shown by comparison of the upper parts of Figures $3 \mathrm{~b}$ and $\mathrm{c}$. What had happened was that a basal ice ledge had grown out from the north (bottom) side of the hole and almost covered the visible bottom. A few dark patches on the ledge, particularly near the wall, probably are exposures of ice, although the ledge is mostly covered with sand and mud. By five days later the visible part of the hole was completely filled by the ledge, and several clasts had appeared on its surface (Fig. 3e). Comparison of Figure $3 \mathrm{~d}$ and e shows that these clasts were undergoing somewhat jumbled translational movement northward relative to the bore-hole walls, which is approximately opposite to what would correspond to downhill sliding. This retrograde motion 
represents either bore-hole closure (see Section 6) or a complex disturbance (such as rolling) of the ice ledge as a result of interaction with the bed underneath. The bright specks along the north-east (lower left) side of the hole in Figure $3 \mathrm{~d}$ and e possibly represent reflections from exposed patches of ice.

The ledge-like feature in hole $\mathrm{X}$ on the right edge of Figure $4 \mathrm{j}-1$ is similar to the ice ledges discussed above in that it evidently has some strength and perhaps even overhangs the debris below it to some extent, but it is not firmly attached to the base of the ice, as shown by its motion relative to the bore-hole walls (Fig. $4 \mathrm{i}-1$ ). This feature is the remnant of a subsole mass of fine- and intermediate-sized debris whose leading edge advances south-westward across the bottom of the hole in the sequence of Figure $4 \mathrm{~b}-\mathrm{f}$ and whose trailing edge departs in the same direction in Figure $4 \mathrm{~g}-\mathrm{l}$. In Figure $4 \mathrm{l}$ a second mass of debris enters the hole from the north-east, and in Photograph B-I 40 it develops a new ledge-like feature on the north side of the hole; this new feature moves faster than the first "ledge" and catches up with it in Photograph B-155. The first "ledge" also moves slower than adjacent large clasts as shown in the sequence of Figure $4 \mathrm{c}-\mathrm{i}$. The slower apparent motion of the first "ledge" implies that it is coupled to the glacier sole to some extent, while the second "ledge" is less well coupled. That these "ledges" may to some extent be cemented by interstitial ice is suggested by their partial similarity to the ice ledges in hole V, but unlike these, the "ledges" in hole X show no visible sign of an ice matrix (dark particles). Also, as argued in Section $5 \mathrm{c}$, their rather weak cohesion implies at most only limited ice cementation. Their existence does however raise the possibility that interstitial ice may occur locally within the subsole drift. The mesa-like shape of the second "ledge" in Photographs B-1 52 and B-1 55 suggests that such cementation was present in a layer only a few centimeters thick at the top of the subsole drift.

A second manifestation of subsole ice related to ice ledges is recognizable in hole $\mathrm{Y}$. The bottom of this hole seen in Figure $5 \mathrm{e}$ and $\mathrm{f}$ is similar in appearance to the top surface of the basal ice ledge in hole $\mathrm{T}$ as seen in Figure $3^{\mathrm{b}}$ and c. Moreover, Figure $5 \mathrm{e}$ and $\mathrm{f}$, and also Photographs B-I 33 , B-I 39 , B-I 50, and B-15I, display dark markings very similar to the dark patches recognized in hole $\mathrm{V}$ as exposures of clear-ice matrix. It thus appears that during part of the observation period in hole $\mathrm{Y}$, the glacier was sliding over a bed consisting of subsole drift impregnated with ice, similar to the material of the basal ice ledges but in this instance not adhering to the sole, at least not fully.

Freezing of interstitial water in the subsole drift can of course account for the development of ice in subsole drift that was previously ice-free. The foregoing evidence from bore-hole photography indicating the presence of ice masses immediately beneath the sole, in the subsole drift, or in the gap between gravel and sole, is reinforced by tunnel observations of subsole ice masses and of ice coating bedrock in subglacial cavities (Kamb and LaChapelle, 1967; Post and LaChapelle, [ ${ }^{\mathrm{c}}$ 1971] , p. 25; Souchez and others, 1973, fig. 2; Vivian and Bocquet, I973, p. 44I). A frozen mud layer 2 to $3 \mathrm{~cm}$ thick between bedrock and ice sole, only partly adhering to the sole, has been observed in a cavity at the base of the Glacier d'Argentière
(Souchez and Lorrain, I975, fig I).

\section{(f) Non-translatory motions}

The presence of a basal gap between the sole and subsole gravel makes it possible for the debris-strewn bed to move past the bottom of the bore-hole walls in simple translatory relative motion, with little disturbance of the loose debris. But tilting, shuffling, or re-arrangement of
the clasts is also commonly visible.

In hole $\mathrm{X}$ this occurred notably when larger clasts that had traversed across the bottom became hung up on the "exit side" and remained there for a time, before moving on out of sight (Fig. 4k, 1; Photographs B-I 42, B-I 45). Such clasts underwent a rolling motion (Fig. $4 \mathrm{a}, \mathrm{b} ; \mathrm{j}-\mathrm{l})$ in the manner appropriate to being caught between the moving ice and the fixed bed. 
Commonly the non-translatory motions consist of irregular shuffiing or seething of the clasts (upper part of Fig. $3 \mathrm{~b}$ and c; Fig. $3 \mathrm{~d}$ and e; Fig. $4 \mathrm{~d}$ and e; Fig. 5e-j). Shifting of clasts with respect to one another is seen in comparing Figure $6 \mathrm{k}$ and 1 . In hole $\mathrm{X}$, irregular tumbling motions were mostly related to collapse of subsole debris banks (Fig. 4). The greatest seething or jumbling occurred in holes $\mathrm{T}$ and $\mathrm{Y}$, where sliding was taking place in the absence of a basal gap; this makes sense mechanically.

There is little evidence that the subsole drift is intruded into the bore holes from under the glacier.* The partial filling of the bottom of hole $\mathrm{C}$ during the interval from Figure $6 \mathrm{~d}$ to $\mathrm{e}$ might represent intrusion but is instead interpreted by us as the result of hole-wall caving of subsole drift during cable-tool drilling (Section 5c). The lack of notable gravel intrusion supports our conclusion that the subsole drift is a very thin layer, particularly if the arguments for subglacial till intrusion by Boulton ( 1976 , p. 293) are correct.

On rare occasions an individual stone can be seen to have moved several centimeters laterally while its neighbors remained relatively unchanged (stone on right in Fig. 5 h reappears in upper center in Fig. 5i ; stone and plastic ball with thread near south side in Photograph No. I63 are found in Photograph No. I66 to have moved north-eastward beyond stones that were near the north side in Photograph No. I63). More commonly, new clasts appear as if from nowhere (Fig. 2d; Fig. 2j, stone in lower left quadrant halfway out from center; Fig. 5h, stone near lower right edge at 4 o'clock; Fig. 6i, triangular stone with quartz vein to left of black dot). When such a stone appears near the "entrance side" of a bore hole in which sliding is in progress with no gap present (such as the stone partly exposed in finer debris near the edge at 8 o'clock in Fig. 5 , or the elongate clast near the north-west (lower right) edge of Fig. 5i), one can reasonably assume that the stone makes its appearance by being worked up into sight from among the generally seething debris around it. In other situations the source of the new stones is less clear. They may have moved laterally from within the bore hole outside the previous field of view or from the gap outside the hole. Or they may have fallen from the bore-hole walls.

The outstanding puzzle of this kind was the sudden appearance in hole $\mathrm{V}$ of the cobble seen in Figure $2 \mathrm{~d}$, blocking the view of the moving bed. It remained in this position for three days, rotating gradually because of the drag of the bed beneath it (Photographs Nos I06, rog, I IO), until we pushed it aside with a sounding weight. For two reasons we consider unlikely the possibility that this cobble fell from the bore-hole walls above: (I) in hole X, in a similar situation, a cobble of similar size in the bore-hole wall showed no sign of coming loose from the wall over a period of two months (Fig. 4); (2) the cobble in hole V was well rounded by abrasion, implying that it had been present at the bed. The triangular stone that appeared suddenly in hole G (Fig. 6i), as mentioned above, was similarly rounded. Probably these clasts rolled or were pushed into their positions in Figures $2 \mathrm{~d}$ and $6 \mathrm{i}$ from somewhere else on the floor of the hole or from the gap between sole and bed. An event in hole X demonstrates the sudden protrusion of a clast from the gap under the bore-hole wall on the "exit side" where this would not be expected (Photographs A-84, A-87).

Lateral displacement of individual clasts could have been caused by lowering the airlift pump inlet or the camera down to rest on the bottom, as must occasionally be done to determine where the bottom is, so that the pump or camera can be set at the proper height to clarify the water or to take a picture. However, it seems that doing this would be more likely to produce a general disturbance of the loose debris on the bottom, rather than a large lateral displacement of an individual clast. Moreover, "sounding" the bottom in this way was done as infrequently and as gently as possible, specifically to avoid such disturbance and to avoid damaging the plexiglass window of the camera. According to the photograph log, no such

* However, marked intrusion of subsole drift occurred in two $264 \mathrm{~m}$ bore holes drilled in a different part of Blue Glacier in 1977 . 
"soundings" were made between taking the photographs in Figure $5 \mathrm{~g}$, h, and i, so that the appearance of the new clast in Figure $5 \mathrm{~h}$ and its lateral displacement in Figure $5 \mathrm{i}$ should not have been due to camera disturbance.

From the above evidence and reasoning we conclude that clasts in the subsole drift occasionally roll or tumble randomly as a result of disturbances caused by basal sliding. Organized rolling motions occur when a clast becomes caught between the moving sole and stationary subsole drift. A general seething of the subsole debris goes on when sliding is occuring in the absence of a basal gap.

The presence of a bore hole must to some extent lead to the occurrence in the subsole drift of non-translatory motions different from those that would take place naturally in the absence of the bore hole. We cannot assess the difference directly from our observations, since they require bore holes, but we can recognize two main causes for a difference. (I) The spatial confinement of the subsole drift by the overlying ice in the absence of the bore hole, and the high confining pressure due to the ice overburden, will tend to inhibit rolling, tumbling, and seething motions that could readily occur under the free surface introduced by the bore hole; these confinement effects will be reduced or eliminated if a gap forms between sole and subsole drift or if the water pressure in the drift approaches the overburden pressure. (2) Clasts can be caught and rolled between moving sole and stationary bed only around the periphery of (or outside of) the bore hole, whereas in the absence of the hole this rolling process can happen anywhere. It therefore seems likely that in the undisturbed (and unobserved) subsole drift, rolling motions directly propelled by the sliding (in a manner analogous to the rolling of balls in a ball bearing) will tend to predominate over the more irregular motions frequently seen in our bore holes.

One can reasonably expect that such rolling motions should lead to rounding of the clasts in the subsole drift. The presence of many unrounded, sharp-edged clasts, such as the clast that is seen to roll in Figure $4 \mathrm{j}-\mathrm{l}$, indicates either that rolling is infrequent or that there is a large nearby basal source of freshly broken rock debris.

\section{(g) Basal water pressure and flow}

An assessment of the water pressure acting at the glacier bed and the associated water flow at the bed is provided by the behavior of water in the bore holes. The level of water standing in the holes was measured by sounding with a float, normally on a daily or nearly daily basis, and on occasion hourly. Daily sounding data for holes drilled in 1969 , and for hole $\mathrm{Z}$ in 1970 , are plotted in Figure 7, and a summary of results for all holes is given in Table II. Our observations are closely related to those recently reported by Hodge ( 1976 ) and Röthlisberger (1976), except that we know which of our holes actually reached the glacier bed where the water pressure of interest is to be sampled.

During drilling, the water in bore holes in the study area, which is above the firn line, always stands initially at a nearly constant, relatively shallow depth near the base of the firn. The initial water levels for the various holes lie in the depth range 6 to I I m (Table II, column 5). We interpret this as the depth of the perched melt-water table at the base of the firn. Normally the water level remains at this constant initial depth without any detectable change until the bed is reached in the drilling and for some time thereafter. Ultimately, however, an abrupt drop in water level usually occurs, and this initiates a period of relatively deep, wildly fluctuating water levels, which may continue for many days (Fig. 7). The length (in days) of the initial period of constant, high water level in each of the holes, counted from the day when the bed was first reached (or, failing this, when the basal debris zone was reached), is given in Table II, column 3. If at a later time the water level returned to its initial height, column 4 gives this time in days counted from the same origin; if by the end of the observation period the initial level had not been recovered, the figure in column 4 is 


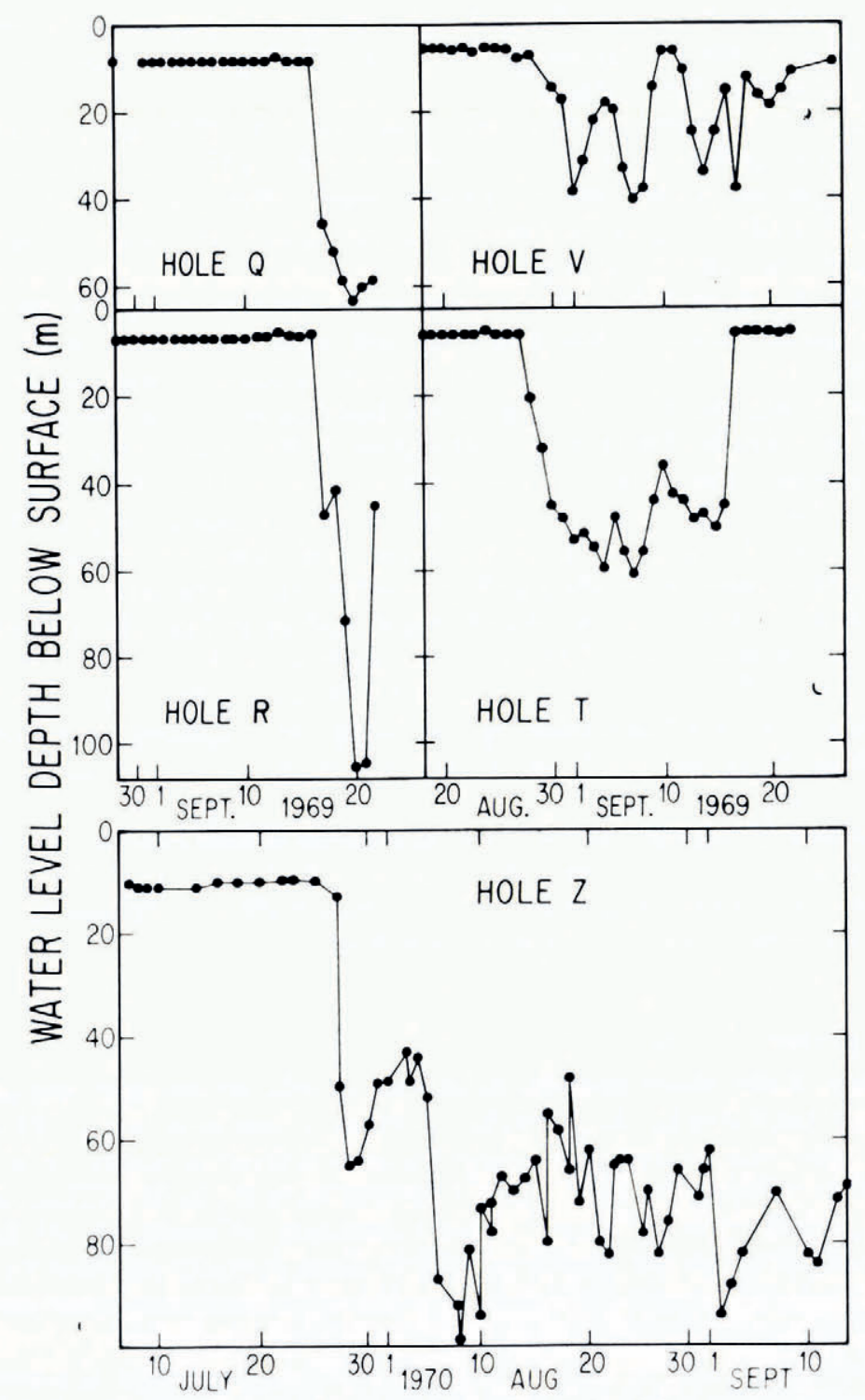

Fig. 7. Daily water-level soundings in bore holes.

preceded by ">". The maximum depth to which the water level was observed to drop in each hole is given in column 6 , and the minimum depth to which it later recovered is given in column 7 .

The water levels dropped greatly from the initial depths in all holes but two. The magnitude of the drop shows that water at the bed has ultimate access to pressures substantially lower than the ice overburden pressure. The initial period of constant high water level is a period when the basal water has not yet communicated with the conduits of lower pressure. During this period the bed is being pressurized by water from the bore hole at a pressure several per cent greater than the ice overburden pressure, as shown by the ratios $\kappa_{0}$ in Table II, 
TABLe II. BehaVior OF WATER LeVELS IN BORE HOLES

\begin{tabular}{|c|c|c|c|c|c|c|c|c|}
\hline \multirow{3}{*}{$\begin{array}{l}\text { Bore } \\
\text { hole }\end{array}$} & 2 & 3 & \multirow{3}{*}{ 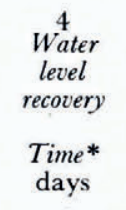 } & \multirow{2}{*}{\multicolumn{3}{|c|}{$\frac{5{ }^{6} \text { Water level depth }^{7}}{\text { After drop }}$}} & \multirow{3}{*}{$\begin{array}{c}8 \\
\\
\text { Bore- } \\
\text { hole } \\
\text { depth } \\
\mathrm{m}\end{array}$} & 9 \\
\hline & \multicolumn{2}{|c|}{ Onset of drop in water level } & & & & & & \\
\hline & Date & $\begin{array}{l}\text { Time* } \\
\text { days }\end{array}$ & & $\underset{\mathrm{m}}{\text { Initial }}$ & $\underset{\mathrm{m}}{\text { Maximum }}$ & $\underset{\mathbf{m}}{\text { Minimum }}$ & & $\kappa_{0} \dagger$ \\
\hline Q & I 7 September 1969 & 73 & $>80$ & 9 & 66 & $6 \mathrm{I}$ & I2I & I.03 \\
\hline $\mathrm{R}$ & 1 7 September I 969 & 62 & $\approx 70 ?$ & 7 & 108 & 47 & 114 & I.04 \\
\hline $\mathrm{T}$ & 27 August 1969 & 46 & 67 & 7 & 64 & 7 & 120 & 1.05 \\
\hline $\mathrm{U}$ & i9July i 969 & o & $\approx \mathrm{IO}$ & I I & 124 & 6 & 124 & I.01 \\
\hline $\mathrm{V}$ & 28 August I 969 & 28 & $4^{1}, \approx 60$ & 6 & $4^{2}$ & 6 & I 19 & I.06 \\
\hline $\mathrm{X}$ & I4 September 1970 & 75 & $>77$ & 6 & $>27$ & - & 123 & 1.06 \\
\hline Y & No drop & $>75$ & - & 6.5 & - & - & 126 & 1.05 \\
\hline$Z$ & 27 July i 970 & 18 & $>60$ & $9 \cdot 5$ & 99 & 44 & 121 & 1.02 \\
\hline C & I 5 August 1976 & 5 & $>27$ & 8.5 & 132 & 87 & 132 & 1.04 \\
\hline D & No drop & $>30$ & - & II.3 & - & - & 132 & 1.02 \\
\hline
\end{tabular}

* From date bore hole reached bottom or basal debris zone.

$\dagger \kappa_{0}=$ Initial ratio of basal water pressure (in bore hole) to overburden pressure, calculated assuming a mean ice density of $0.9 \mathrm{Mg} \mathrm{m}^{-3}$.

column 9. Except in areas of sufficiently great basal stress concentration, this pressurization will cause the ice to separate from the bed and will thereby open up passageways along which water can leak away from the hole. Initially the permeability of the bed to such leakage is so small that the source of water in the firn is more than sufficient to maintain the water level. Ultimately the new passageways, spreading out from the bore hole, make a good enough connection with the natural conduits at lower pressure so that water then begins to leak away rapidly and the level cannot be maintained by inflow from the firn.

A clear example of connection to a low-pressure conduit was provided by bore hole $\mathrm{U}$, which by chance bottomed very close to a subglacial stream. The evidence for this is as follows. The thermal drill was not slowed by dirty ice prior to reaching the bed, but stopped abruptly, and the water level then dropped immediately to a depth of I I I m, only I3 m above the bottom. By $5 \mathrm{~d}$ later, the water level had dropped all the way to the bottom. The sounding float did not come to a stop at the bottom, but instead continued to run out as far as we chose to let it, a distance of $65 \mathrm{~m}$ beyond the bottom of the hole. It was evidently being carried down along the bottom of the glacier in a subglacial stream. Upon being hauled in, it jammed irretrievably at the bottom of the hole, showing that the connection from the bottom of the hole to the subglacial stream was through a narrow passageway; this is consistent with the earlier observation that the water level did not drop all the way to the bottom initially. About five days later the water level rose back to near the surface, showing that the narrow passage had by then become sealed off. These observations provide direct evidence for the existence of a subglacial stream at essentially atmospheric pressure and for opening and closing of a narrow passageway through which bore-hole water gained access to the stream.

From hole $\mathrm{C}$ a connection was established to a low-pressure conduit in only $5 \mathrm{~d}$, and the water level in the hole ultimately dropped all the way to the bottom. Since hole C was only $23 \mathrm{~m}$ from the original location of hole $\mathrm{U}$, it is very likely that the conduit that was reached was the same subglacial stream encountered in hole U. In hole $\mathrm{Z}$ the water level dropped to within $20 \mathrm{~m}$ of the bottom. Running water could be heard in this hole, and air was drawn conspicuously down it, causing pronounced enlargement of the hole. This suggests that the hole connected via an intraglacial conduit to a subglacial channel at atmospheric pressure. In hole $\mathrm{R}$ the water level ultimately dropped almost to the bottom, even though this hole was 
not completed with cable-tool drilling and therefore probably did not penetrate all the way to the bed.

From the above evidence we conclude that the basal water pressure in subglacial water conduits under the study area was essentially atmospheric during the period of observation. The bore holes in which the water levels did not drop all the way to the bottom do not indicate higher basal water pressures, but instead show that the passageways that open up to provide a connection with the subglacial water conduits are often rather constricted, so that their water-carrying capacity is marginal and fluctuating. This is responsible for the wide fluctuations in water levels in these holes, and is consistent with the fact that the passageways sometimes seal up so that the initial water levels are recovered (Fig. 7).

Hole $\mathrm{Y}$ is the unly hole that definitely reached the bed but did not experience any drop in water level. This shows that locally the bed can for practical purposes be impenetrable to water under a pressure significantly greater than the overburden pressure. The failure of basal passageways to open up by ice-bed separation under a water pressurization $5 \%$ greater than the ice overburden pressure could be the consequence of a stress concentration in the basal ice around the bore hole. Alternatively, the presence of ice in the subsole drift at hole Y (see Section 5e) might have been responsible for an abnormally good "seal" at the bottom of this hole. This explanation is compatible with the behavior of hole $\mathrm{D}$, which was not completed by cable-tool drilling to the bed, and which experienced no drop in water level during the period of observation. Holes $\mathrm{Q}$ and $\mathrm{R}$ were observed longer, and demonstrate that connections to the subglacial conduits can ultimately open up from holes not driven all the way to the bed by cable-tool drilling. This conclusion was also reached by Hodge (1976).

The marked though only partial correlation between water-level fluctuations in holes $Q$ and $\mathrm{R}$ and again between holes $\mathrm{T}$ and $\mathrm{V}$ (Fig. 7) might suggest that these fluctuations reflect real patterns of pressure variation in the subglacial conduits. But this is made quite improbable by the great difference between these two pairs of holes, and between them and hole $\mathrm{U}$, also nearby (Fig. Ib). Instead, we infer from the correlations that the water leakage pathways opened up by basal water pressurization from bore holes can extend out over distances $\approx 50 \mathrm{~m}$ away from the holes. Bore holes separated by such distances can thus become connected to subglacial water conduits via the same passageway system, so that their water levels, being controlled by the same constrictions of the passageways, will fluctuate synchronously. This is plausible if the subglacial streams are spaced $c .50 \mathrm{~m}$ or more apart.

Further insight into the behavior of water at the bed is provided by turbidity in the borehole bottom water. During an initial period in every hole, turbidity was a continuous problem for bore-hole photography: water-pumping with the air-lift pump had to be done before almost every picture in order to get a clear or even partly clear view. This was the situation in hole $\mathrm{X}$ for about a month, and in hole $\mathrm{Y}$ for about $\mathrm{I} 5 \mathrm{~d}$. Later the bottom water spontaneously became clear, and remained clear if the bottom was not subsequently disturbed, which indicates that by this time either a flocculation process of particle settling had become effective or there was an appreciable outflow of water into the subsole drift. This occurred after $12 \mathrm{~d}$ in hole $\mathrm{T}, \mathrm{I} 7 \mathrm{~d}$ in hole V, and only $5 \mathrm{~d}$ in hole $\mathrm{C}$. Once the water level in the hole dropped, which in most holes occurred some time after the onset of spontaneous clarification, the bottom water was always clear, even after cable-tool drilling. These observations show that the water escapes from the holes at the bottom, either into the subsole drift or into the gap between ice and drift, if present. (Hole $\mathrm{Z}$ was an exception: photography indicated that water was leaking from the hole at a height of about I $\mathrm{m}$ above the bottom.)

Before spontaneous clarification begins, the subsole drift behaves as though it were extremely impermeable. This is particularly evident in hole $\mathrm{Y}$, where pictures consistently

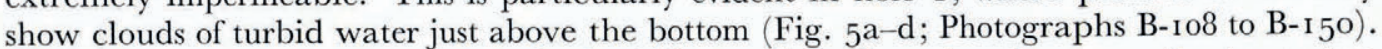
The flow of water down into the subsole drift must have been less than a centimeter or two per day, otherwise these clouds would have been carried down out of sight over the period of 
many days of observation. The permeability implied is much lower than would be needed only to explain high-standing water levels, because the water inflow from the firn is substantial. We can set an upper limit on the apparent permeability of the subsole drift around hole $\mathrm{Y}$ if we assume that the downflow velocity is less than $\mathrm{I} \mathrm{cm} / \mathrm{d}$, that the subsole drift layer is $10 \mathrm{~cm}$ thick, and that the low-pressure conduits lie at an average distance of $50 \mathrm{~m}$ from the hole. The indicated permeability limit is $\left\langle c .10^{-5}\right.$ darcy $\left(\mathrm{cm}^{2} \mathrm{bar}^{-1} \mathrm{~s}^{-1}\right)$. This is two orders of magnitude below the lower limit of about $\mathrm{IO}^{-3}$ darcy observed for the most impermeable unlithified sediments (clay-rich sands), and corresponds to the most impermeable solid rocks (shales and crystalline rocks). For hole $\mathrm{Y}$ this can be explained by interstitial ice in the subsole drift, as noted above, but for hole $\mathrm{X}$ such an explanation is inapplicable. The subsole drift, there is obviously permeable because it displays visible openings and voids (Fig. 4), yet lingering turbidity remained a problem in this hole for a month despite repeated water pumping.

These observations can be rationalized by inferring that the bore-hole locations are encircled at a distance by strong permeability barriers, which normally block fluid communcation between the subsole drift and the subglacial conduits at low pressure. Interconnected areas of the bed where subsole drift is absent and ice is in direct contact with bedrock could provide such barriers.

We surmise that the leakage passageways that ultimately make a connection from the bore holes to the subglacial water conduits, through the sealed regions of the bed, open up initially by invasion of pressurized bore-hole water along routes across the bed where the compressive stress across the ice-bed interface is a minimum. They subsequently become enlarged by melting of overlying ice as a result of heat dissipation by water flow through them, and because of this enlargement, they tend to be carried down-stream by the moving ice, especially when the bore-hole water pressure drops to the point where it alone is no longer sufficient to keep the passageways open at their original location on the bed. The fluctuating capacity of the leakage passageways, and their eventual sealing up, result from changes in basal compressive stress and in heating due to water flow, there being a delicate balance between passageway enlargement by melting and closure by ice flow under the local compressive stress. This stress fluctuates but generally increases as the passageways are carried down-stream from their place of origin. The total displacement of the bore holes by sliding at the bottom during the period when their water levels were being monitored ranges from 6 to $70 \mathrm{~cm}$ for the different holes, hence significant fluctuations in basal stress appear to occur over these distances.

In hole $\mathrm{Y}$ the clouds of turbidity that were seen lurking just above the bottom and obscuring its deeper levels (Fig. 5a-d), during a period when air-lift pumping was repeatedly done to remove the turbid bottom water, suggest that turbidity was being continuously generated and introduced into the bore-hole water at the bottom. This was probably caused by internal motions in the subsole drift, caused by the sliding. Other holes showed such turbidity clouds only rarely and weakly (e.g. Fig. 4k, l), probably because the downflow of water into the subsole drift was generally greater than in hole Y.

While the water-level observations demonstrate that water pressures are low in the subglacial conduit system whose pressure influences the extent of basal cavitation (Kamb, I97o, p. 720), they do not provide a direct indication of the water pressure that exists in the pore space of the subsole drift prior to penetration of bore holes into it. If the inherent hydraulic permeability of the subsole drift were high, the natural pore pressure in the subsole drift would be the same as the pressure in the subglacial conduits, since only a small source of pore water is available in the subsole drift, from bottom melting. But the evidence (above) for very low permeability of the subsole drift, or for interconnecting permeability barriers in the ice-bed interface, allows the possibility that the natural pore pressure may be substantially higher and may approach the ice overburden pressure. A pore pressure of this magnitude could explain 
the otherwise very puzzling failure of the glacier ice to invade the subsole drift completely, down to the bedrock. This invasion should take place rapidly under the action of regelation if the full overburden pressure of the ice were borne by the subsole drift without the help of a nearly equal pore pressure.

\section{Sliding motion}

\section{(a) Quantitative results of bore-hole photography}

Sliding velocities derived from bore-hole photography are given in Table III (columns I I-12). They are based on the displacements of individual bed features (mostly individual clasts) with respect to features at the bottom of the bore-hole walls, as seen in successive borehole photographs. The time intervals represented by the sliding velocities quoted are defined by the photographs used (Table III, column I3), which were taken at the times given in the figure captions.

The acccuracy with which a given object on the bed can be located with respect to reference features in the bore-hole walls is dependent on the scale, the photographic resolution achieved, and the sharpness of the features involved, but is generally $\mathrm{I} \mathrm{mm}$ or better. In deriving velocities from pairs of photographs the main sources of error are the variation of scale from one photograph to the next, possible changing parallax due to the gap between the bottom of the bore-hole walls and the bed, and possible bore-hole contraction. The scale

TABle III. Surface Flow AND BASAL SLIDING Velocities

\begin{tabular}{|c|c|c|c|c|c|c|c|c|c|c|c|c|c|}
\hline I & 2 & 3 & 4 & 5 & 6 & 7 & 8 & 9 & 10 & 11 & 12 & 13 & 14 \\
\hline \multirow[b]{2}{*}{$\begin{array}{l}\text { Bore } \\
\text { hole }\end{array}$} & \multicolumn{4}{|c|}{ Surface flow velocity } & \multicolumn{3}{|c|}{$\begin{array}{l}\text { Difference between surface and bed } \\
\text { velocities from inclinometry }\end{array}$} & \multicolumn{2}{|c|}{$\begin{array}{l}\text { Sliding velocity } \\
\text { from surface } \\
\text { velocity and } \\
\text { inclinometry }\end{array}$} & \multicolumn{4}{|c|}{$\begin{array}{c}\text { Sliding velocity from bore-hole } \\
\text { photography }\end{array}$} \\
\hline & $\begin{array}{l}\text { Hori- } \\
\text { zontal } \\
\text { com- } \\
\text { ponents } \\
\mathrm{cm} / \text { day }\end{array}$ & $\begin{array}{l}\text { Direc- } \\
\text { tion } \\
\text { deg }\end{array}$ & $\begin{array}{c}\text { Plunge } \\
\text { deg }\end{array}$ & $\begin{array}{c}\text { Observed } \\
\text { interval } \\
\text { (inclusize dates) }\end{array}$ & $\begin{array}{l}\text { Hori- } \\
\text { zontal } \\
\text { com- } \\
\text { ponents } \\
\mathrm{cm} / \text { day }\end{array}$ & $\begin{array}{l}\text { Direc- } \\
\text { tion } \\
\text { deg }\end{array}$ & $\begin{array}{c}\text { Observed } \\
\text { interval } \\
\text { (inclusive dates) }\end{array}$ & $\begin{array}{l}\text { Hori- } \\
\text { zontal } \\
\text { com- } \\
\text { ponents } \\
\mathrm{cm} / \text { day }\end{array}$ & $\begin{array}{l}\text { Direc- } \\
\text { tion } \\
\text { deg }\end{array}$ & $\begin{array}{l}\text { Hori- } \\
\text { zontal } \\
\text { com- } \\
\text { ponents } \\
\mathrm{cm} / \mathrm{day}\end{array}$ & $\begin{array}{l}\text { Direc- } \\
\text { tion } \\
\text { deg }\end{array}$ & $\begin{array}{l}\text { Photo- } \\
\text { graph } \\
\text { pair } \\
\text { Fig. }\end{array}$ & $\begin{array}{l}\text { Mea- } \\
\text { sured } \\
\text { interval } \\
\text { days }\end{array}$ \\
\hline $\mathrm{T}$ & 14.7 & N61E & 10.8 & $\begin{array}{l}29 \text { July } 1969 \\
16 \text { August } 1969\end{array}$ & - & - & - & - & - & $\begin{array}{l}1.3 \\
\pm 0.5\end{array}$ & $\begin{array}{l}\mathrm{N}_{33} \mathrm{E} \\
\pm 15\end{array}$ & $3 b-c$ & 0.2 \\
\hline \multirow[t]{3}{*}{ V } & 13.7 & $\mathrm{~N}_{5} 6 \mathrm{E}$ & $9 \cdot 9$ & $\begin{array}{l}29 \text { July } 1969 \\
16 \text { August } 1969\end{array}$ & - & - & - & - & - & $\begin{array}{l}1.1 \\
\pm 0.2\end{array}$ & $\begin{array}{l}\mathrm{N}_{54} \mathrm{E} \\
\pm 15\end{array}$ & $2 a-b$ & 1.1 \\
\hline & & & & & & & & & & $\begin{array}{l}2.7 \\
\pm 0.2\end{array}$ & $\begin{array}{c}\mathrm{N}_{43} \mathrm{E} \\
\pm 7\end{array}$ & $2 \mathrm{~h}-\mathrm{i}$ & 1.0 \\
\hline & & & & & & & & & & $\begin{array}{l}2.9 \\
\pm 0.2\end{array}$ & $\begin{array}{c}\mathrm{N}_{49} \mathrm{E} \\
\pm 7\end{array}$ & $2 \mathrm{k}-\mathrm{m}$ & 1.0 \\
\hline \multirow[t]{3}{*}{$\mathbf{Y}$} & 16.0 & $\mathrm{~N} 62 \mathrm{E}$ & 10.3 & $\begin{array}{l}26 \text { June } 1970 \\
28 \text { August } 1970\end{array}$ & - & - & - & - & - & $\begin{array}{l}1.0 \\
\pm 0.5\end{array}$ & $\begin{array}{l}\text { N3oE } \\
\pm 25\end{array}$ & $5 \mathrm{c}-\mathrm{d}$ & 0.2 \\
\hline & & & & & & & & & & $\begin{array}{l}0.7 \\
\pm 0.2\end{array}$ & $\begin{array}{l}N_{30 E} \\
\pm 10\end{array}$ & $5^{e-f}$ & 0.9 \\
\hline & & & & & & & & & & $\begin{array}{l}0.5 \\
\pm 0.2\end{array}$ & $\begin{array}{l}\mathrm{N}_{49} \mathrm{E} \\
\pm 7\end{array}$ & $5 \mathrm{~g}-\mathrm{j}$ & 3.0 \\
\hline \multirow[t]{5}{*}{$\mathrm{x}$} & $\begin{array}{l}14.6 \\
\pm 0.1\end{array}$ & $\begin{array}{l}\mathrm{N} 63 \mathrm{E} \\
\pm 0.4\end{array}$ & 12.1 & $\begin{array}{l}26 \text { June } 1970 \\
28 \text { August } 1970\end{array}$ & $\begin{array}{l}12.6 \\
\pm 0.4\end{array}$ & $\mathrm{~N}_{54} \mathrm{E}$ & $\begin{array}{l}24 \text { June } 1970 \\
28 \text { August } 1970\end{array}$ & $\begin{array}{l}2.9 \\
\pm 0.7\end{array}$ & $\begin{array}{l}\mathrm{N}_{105} \mathrm{~F} \\
\pm 22\end{array}$ & $\begin{array}{l}0.7 \\
\pm 0.1\end{array}$ & $\begin{array}{l}\mathrm{N}_{95} \mathrm{E} \\
\pm 5\end{array}$ & $4 a-d$ & $7 \cdot 3$ \\
\hline & & & & & & & & & & $\begin{array}{l}0.6 \\
\pm 0.1\end{array}$ & $\begin{array}{c}\mathrm{N} 82 \mathrm{E} \\
\pm 5\end{array}$ & $4^{f-g}$ & 5.1 \\
\hline & & & & & & & & & & $\begin{array}{l}0.8 \\
\pm 0.2\end{array}$ & $\begin{array}{l}\mathrm{N} 8{ }_{3} \mathrm{E} \\
\pm 10\end{array}$ & $4 g-h^{*}$ & 2.2 \\
\hline & & & & & & & & & & $\begin{array}{l}1.4 \\
\pm 0.2\end{array}$ & $\begin{array}{l}\mathrm{N}_{72} \mathrm{E} \\
\pm 7\end{array}$ & $4 g-h^{*}$ & 2.2 \\
\hline & & & & & & & & & & $\begin{array}{l}1.0 \\
\pm 0.2\end{array}$ & $\begin{array}{l}\text { N7oE } \\
\pm 7\end{array}$ & $4^{\mathrm{h}-\mathrm{i}}$ & 2.7 \\
\hline \multirow[t]{2}{*}{ C } & $\begin{array}{l}16.2 \\
\pm 0.2\end{array}$ & $\begin{array}{l}\mathrm{N} 62 \mathrm{E} \\
\pm 0.7\end{array}$ & II. I & $\begin{array}{r}13 \text { August } 1976 \\
6 \text { September } 1976\end{array}$ & $\begin{array}{l}16.2 \\
\pm 0.7\end{array}$ & $\begin{array}{l}\mathrm{N}_{3} \mathrm{E} \\
\pm 2\end{array}$ & $\begin{array}{l}10 \text { August } 1976 \\
5 \text { September } 1976\end{array}$ & $\begin{array}{c}0.2 \\
\pm 0.8\end{array}$ & $\begin{array}{l}N_{15} W \\
\pm 180\end{array}$ & $\begin{array}{l}0.3 \\
\pm 0.4\end{array}$ & (N6oE) & $6 c-\dagger$ & 0.7 \\
\hline & & & & & & & & & & $\begin{array}{l}0.3 \\
\pm 0.1\end{array}$ & $\begin{array}{l}\mathrm{N}_{4} \mathrm{OE} \\
\pm 10\end{array}$ & $6 c-e$ & $7 \cdot 7$ \\
\hline
\end{tabular}

* Two entries for the same photograph pair represent two distinct motions observed simultaneously; see text, Section 6 . $\dagger$ Photograph B-197. 
can be controlled by distances between reference points on the bed visible in both photographs, or between points in the bore-hole walls if near the bed and if contraction is not significant. The scale itself, which does not generally need to be known as accurately as the relative scales of the two photographs, is determined by the methods discussed by $\mathrm{H}$ \& $\mathrm{K}$ (p. 132). Our overall assessment, based on the foregoing factors, is that sliding velocities obtained over a time interval of one day have an accuracy of about $0.4 \mathrm{~cm} / \mathrm{d}$; the error decreases inversely with the time interval (given in Table III, column 14). Error in the direction of sliding is about $20^{\circ}$ for an observed displacement of $\mathrm{I} \mathrm{cm}$, and decreases inversely with the displacement; individual error assessments are given in Table III, column I I.

Observed sliding velocities are in the range 0.3 to $3 \mathrm{~cm} / \mathrm{d}$; they average $1.0 \mathrm{~cm} / \mathrm{d}$ for the five successful bore holes (Table III). These velocities are substantially smaller than the $6 \mathrm{~cm} / \mathrm{d}$ that we originally expected on the basis of earlier deformation measurements in thermally drilled bore holes (Kamb and Shreve, I 966), which suggested a sliding rate about half the surface velocity of $\approx 15 \mathrm{~cm} / \mathrm{d}$ (Table III, column 2). The direction of sliding found by bore-hole photography (Table III, column I2) is generally within about $20^{\circ}$ of the direction of surface motion (Table III, column 3), the maximum deviation being about $30^{\circ}$.

Although the errors of measurement are substantial, the differences among the sliding velocities observed in the different holes are significant. They represent both lateral variations in sliding velocity at a given time and also, probably, variations from year to year. The various observed velocities do not fall into a systematic pattern when viewed spatially (Fig. Ib). The highest velocity (near $3 \mathrm{~cm} / \mathrm{d}$ ) was seen in hole $\mathrm{X}$, and the lowest in hole $\mathrm{C}(\mathrm{o.3}$ $\mathrm{cm} / \mathrm{d}$ ), which was located only about $20 \mathrm{~m}$ away (Fig. Ib). Independent evidence (to be published separately) suggests that the sliding rate in 1976 was unusually small, in agreement with the observations in the hole C. The difference between the velocity of $1.0 \mathrm{~cm} / \mathrm{d}$ at hole T on 5 September and of about $3 \mathrm{~cm} / \mathrm{d}$ at $\mathrm{V}$ over a period of about ${ }_{1} 5 \mathrm{~d}$ including 5 September is a real spatial variation between two points on the bed $28 \mathrm{~m}$ apart. On the other hand, holes $\mathrm{X}$ and $\mathrm{Y}, 6 \mathrm{om}$ apart, showed essentially the same velocity within the accuracy of measurement.

In addition to the possible year-to-year variation suggested above, there is evidence for a time variation of sliding velocity at hole $\mathrm{V}$ over the period of observation in 1969 . Velocities measured from successive pairs of photographs are plotted as a function of time in Figure 8. The initially observed velocity of about $1.5 \mathrm{~cm} / \mathrm{d}$ increased sometime during the interval 2 I-25 August to about $3.0 \mathrm{~cm} / \mathrm{d}$ and remained at this level for the remainder of the observation period. The increase occurred during the time when the bottom of the hole was hidden by a cobble (Fig. 2d), so that we could not monitor the velocity over this interval. The velocity increase correlates with the first incipient signs of drop in water level in the hole (Fig. 8). This correlation, if not accidental, could imply either that the increase in sliding velocity caused increased ice-bed separation which in turn promoted drainage of water from the bore hole, or, conversely, that pressurization of the bed by the bore hole caused increased basal separation which in turn resulted in an acceleration in sliding rate. The latter alternative would be especially noteworthy in representing a situation where the sliding velocity of a glacier was locally affected by an action of man (basal pressurization from the bore hole). However, doubt as to the causative role of basal pressurization is cast by the situation at hole $\mathrm{T}$, where, although the water level dropped as it did at hole $\mathrm{V}$, apparently no velocity increase occurred (since the sliding velocity was only $\mathrm{I} \mathrm{cm} / \mathrm{d}$ when measured on 5 September). In view of the observed lateral variations in sliding velocity, it is possible that the velocity variation in hole $\mathrm{V}$ was due to passage of the bore hole through a laterally varying slidingvelocity field rather than to a time variation, but we consider this unlikely because of the abruptness of the observed change in sliding velocity (Fig. 8).

In some instances two separate velocities are observed simultaneously in a given pair of photographs. In Figure $4 \mathrm{~g}$ and $\mathrm{h}$, the large stone coming into view from the left is moving 


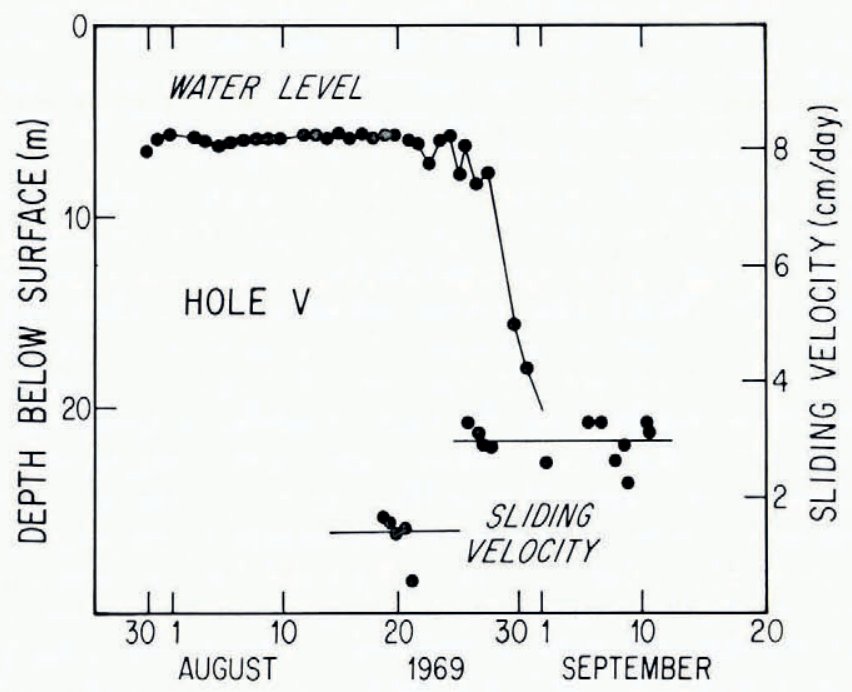

Fig. 8. Comparison of measurements of sliding velocity and water level in bore hole $V$. The water levels include only the early part of the data for hole $V$ in Figure 7.

decidedly faster than, and is catching up with, the smaller clast near the top (south) and the gravel mass in which the latter is imbedded. The two velocities $(1.3$ and $0.8 \mathrm{~cm} / \mathrm{d}$ ) corresponding to these two translational motions are listed as separate entries in column I I of Table III, opposite hole X. Obviously not both of these figures can represent the actual sliding velocity. The slower apparent motion of the gravel mass implies that this mass is being partially dragged along by the moving ice. In the interval from Figure $4 \mathrm{~h}$ to $\mathrm{i}$ the large stone continues its relatively fast motion, but its apparent velocity has decreased to $1.0 \mathrm{~cm} / \mathrm{d}$. Later, in Figure $4 \mathrm{j}-1$, the large stone hangs up on the "exit" edge of the bore hole, and a gravel mass moving in from the lower left begins to catch up to it.

From the observation of definitely different motions occurring simultaneously we are led to believe that the larger differences in motion among the entries for hole $\mathrm{X}$ in Table III (column II) probably reflect real variations in observable motion rather than apparent variations due to fluctuating measurement errors. But they clearly raise a problem as to how the observed motions relate to the actual sliding motion.

There are two reasons for taking as the sliding velocity the largest of the apparent motions observed at a given time (or over a period of time if variations in sliding with time can be assumed not to occur during this period): (I) Dragging of basal debris along by the ice will reduce the apparent motions. (2) If clasts execute rolling motions while caught between moving sole and fixed bed, their apparent motion will be half the sliding velocity if judged by the motion of the sides of the clast, or zero if judged by the motion of the top of the clast. If such rolling motions are common among the larger clasts, in a "ball-bearing-like" mode of basal sliding, then masses of finer debris between the larger clasts will be constrained to move along at a speed of half the sliding velocity.

The directions of sliding motion seen in successive time periods at hole $\mathrm{X}$ (Table III, column 12) vary by about $25^{\circ}$. We consider this variation to be real, because individual azimuths of motion can be measured in this photographic sequence to a precision of about $5^{\circ}$ on a relative basis. These variations represent either time variations in the sliding direction or differences in the coupling of the subsole drift to the moving ice. The two distinct motions seen in photograph pair of Figure $4 \mathrm{~g}-\mathrm{h}$ have directions that differ by $10^{\circ}$, which, though not 
large, is a real difference. It demonstrates that distinct alterations in the apparent direction of motion can be produced by changes in coupling of ice and subsole drift, and that the apparent direction of motion can be altered from the actual sliding direction. How this happens is not evident, although we can surmise that the asymmetric rolling of larger clasts of odd shape could be responsible.

On the basis of the experience in hole $\mathrm{X}$ we believe that the differences among the observed azimuths of motion of the various holes (Table III, column 12) are significant although doubtless affected by substantial scatter $\left( \pm 10^{\circ}\right.$ to $\left.15^{\circ}\right)$ due to measurement errors. In particular, the difference of $60^{\circ}$ in observed azimuth between hole $\mathrm{T}$ and hole $\mathrm{X}$ is a real difference. It represents observations made only $\mathrm{I} 5 \mathrm{~m}$ apart, in two successive years. From striations on glaciated bedrock surfaces, both around the periphery of Blue Glacier and quite generally in glaciated terrains (e.g. Chamberlin, I888), it is of course well known that the direction of the sliding motion can change with time, and can change laterally over distances of as little as a few centimeters under appropriate flow constraints from bedrock topography. The change in direction from hole $\mathrm{T}$ to hole $\mathrm{X}$ seems nevertheless too large to be a time variation in sliding motion from one year to the next; it seems possible for a lateral variation if the bed has high roughness on a scale of ten meters or less.

The very low sliding velocity at hole $\mathrm{C}$ stands out as anomalous in relation to the other bore holes. The motion is so small that it cannot be recognized clearly in any photograph pairs except Figure 6c-e and, marginally, Photographs B-I 96-197. It is entirely possible that no sliding at all was occurring at times during the observation period. In several photograph pairs an apparently retrograde motion is seen, which is a falsification due to contraction of the bore-hole walls. Bore hole $\mathrm{C}$ closed at a rate of about $2 \mathrm{~cm} / \mathrm{d}$ (contraction of diameter) near the bottom. The contraction can be seen by comparing Figure $6 \mathrm{c}$ and $\mathrm{d}$, although the smaller scale of Figure $6 \mathrm{~d}$ exaggerates the effect. For objects on the bed near the north-east side of the hole, which in some photographs was the only available reference for observing the sliding motion, the contraction results in an apparent retrograde motion (apparent sliding in a southwest direction) of about $\mathrm{I} \mathrm{cm} / \mathrm{d}$. This large disturbing effect made it difficult to observe the small sliding velocity reliably over periods of a few days. Longer periods could not be used because, to offset the contraction, the hole frequently had to be reamed or redrilled, which disturbed or obliterated features in the bore-hole walls used for motion reference; also, attempts to reveal bedrock by cable-tool drilling and bailing repeatedly disturbed the bottom. The bore-hole contraction rate was much larger in hole $\mathrm{C}$ than in the other holes because of the consistently low stand of the water level in this hole.

\section{(b) Tests by the indirect method}

Because the sliding motions observed by bore-hole photography are anomalously low in relation to what was expected, and because the full sliding motion may sometimes not be displayed by bore-hole photography, as the foregoing discussion indicates, it is helpful to have an independent check on the sliding velocity. This is provided by bore-hole inclinometry in holes $\mathrm{X}$ and $\mathrm{C}$. In hole $\mathrm{X}$ the measurements were made with an electrical inclinometer previously used by Raymond (197I), while in hole C a new type of electrical inclinometer, designed and built by Phil Taylor at the University of Washington, was used. Figure 9 shows the results in terms of the deformation of the two bore holes: the horizontal components of displacement of the initially vertical bore holes are plotted as a function of depth below the surface. The displacements are shown in terms of displacement rates by dividing the observed displacements by the time interval between initial and final determinations of bore-hole configuration $(64.5 \mathrm{~d}$ for hole $\mathrm{X}, 25.8 \mathrm{~d}$ for hole C). The components are resolved in the direction of the surface velocity vector and perpendicular thereto. The displacement rate at the surface relative to the bore-hole bottom is given in Table III, columns 6 and 7. The 
absolute flow velocity at depth is obtained by subtracting this relative displacement vectorially from the surface motion, measured by triangulation from bedrock during the period of borehole observations (Table III, columns 2-5). The results are given in Table III (columns 9 and 10 ) and also in Figure 9, where, by appropriate choice of origin, the plotted displacements represent absolute components of motion (relative to bedrock).

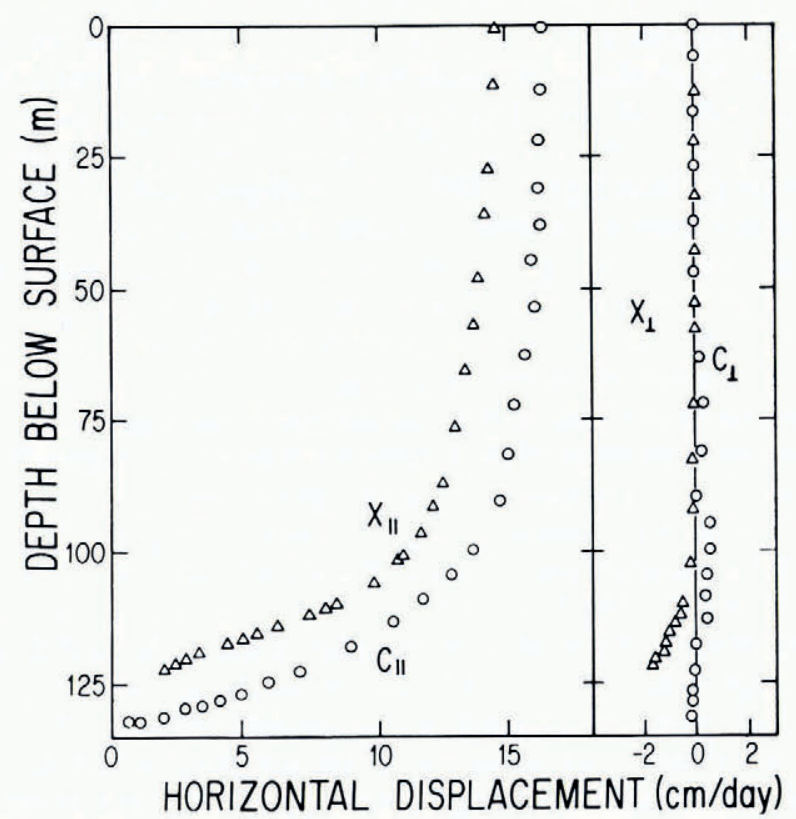

Fig. 9. Horizontal components of flow velocity at depth in bore holes $X$ and $C$, obtained by combining surface-velocity measurements with integrated inclinometry data. Velocity component in a vertical plane parallel to the surface velocity vector are plotted on the left (labelled $X_{\|}$and $\left.C_{1}\right)$, and perpendicular to this plane on the right $\left(X_{\perp}\right.$ and $\left.C_{\perp}\right)$, triangles and circles respectively.

The absolute velocities derived in this way at the bottom of the bore holes should be the sliding velocities if the bore holes reached the bed, and should agree with the velocities determined by bore-hole photography if the full sliding motions were displayed at the bottom of the holes. The comparison is in Table III. There is general agreement in the sense that the sliding velocities found by both methods are small, much less than half the surface motion. Also, the larger sliding motion inferred from inclinometry corresponds to the larger motion observed by bore-hole photography. However, there is some disagreement in detail, particularly as to the azimuths of the sliding velocity.

To assess the significance of the disagreements, we give the estimated precisions of the velocities derived from surveying and inclinometry, indicated by the \pm figures in Table III (columns 2-7). Because the inferred sliding motion is obtained as the difference of two nearly equal vectors, its magnitude and especially its direction are sensitive to errors in direction of these vectors. This is reflected in the relatively large errors given in columns 9 and 10 , which represent the uncertainties due to random measurement errors. The inferred azimuth of sliding for hole $\mathrm{C}$ is completely undetermined, because the sliding rate is so small. For hole $\mathrm{X}$ we believe that possible systematic errors in the compass calibration are responsible for the large discrepancy between azimuths of surface velocity and inferred sliding. A systematic error of about $9^{\circ}$ in compass calibration, which is readily admissible for the instrument, would 
account for the azimuth discrepancy. If the compass directions are corrected to eliminate this discrepancy, so that the inferred sliding azimuth becomes $\mathrm{N} 63^{\circ} \mathrm{E}$, then the inferred sliding velocity at hole $\mathrm{X}$ becomes $\mathrm{I} 4.6-\mathrm{r} 2.6=2.0 \pm 0.7 \mathrm{~cm} / \mathrm{d}{ }^{*}$ This is in tolerable agreement with the largest of the sliding motions observed in hole X by bore-hole photography $(\mathrm{I} \cdot 3 \pm 0 . \mathrm{I} \mathrm{cm} / \mathrm{d})$.

We therefore conclude that the indirect method of determining the sliding velocity from surveying and inclinometry confirms the direct measurements of sliding velocity by bore-hole photography, to within the not inconsiderable errors involved in these methods. This confirms that the glacier bed, where sliding occurs, has indeed been reached in our drilling. From the comparison in Table III it is evident that the accuracy of sliding-velocity measurement achievable by bore-hole photography, even with the evident difficulties involved, is significantly better than that of the indirect method. Moreover, any non-zero sliding measured by the indirect method is inherently unreliable unless cable-tool drilling (or equivalent) has been

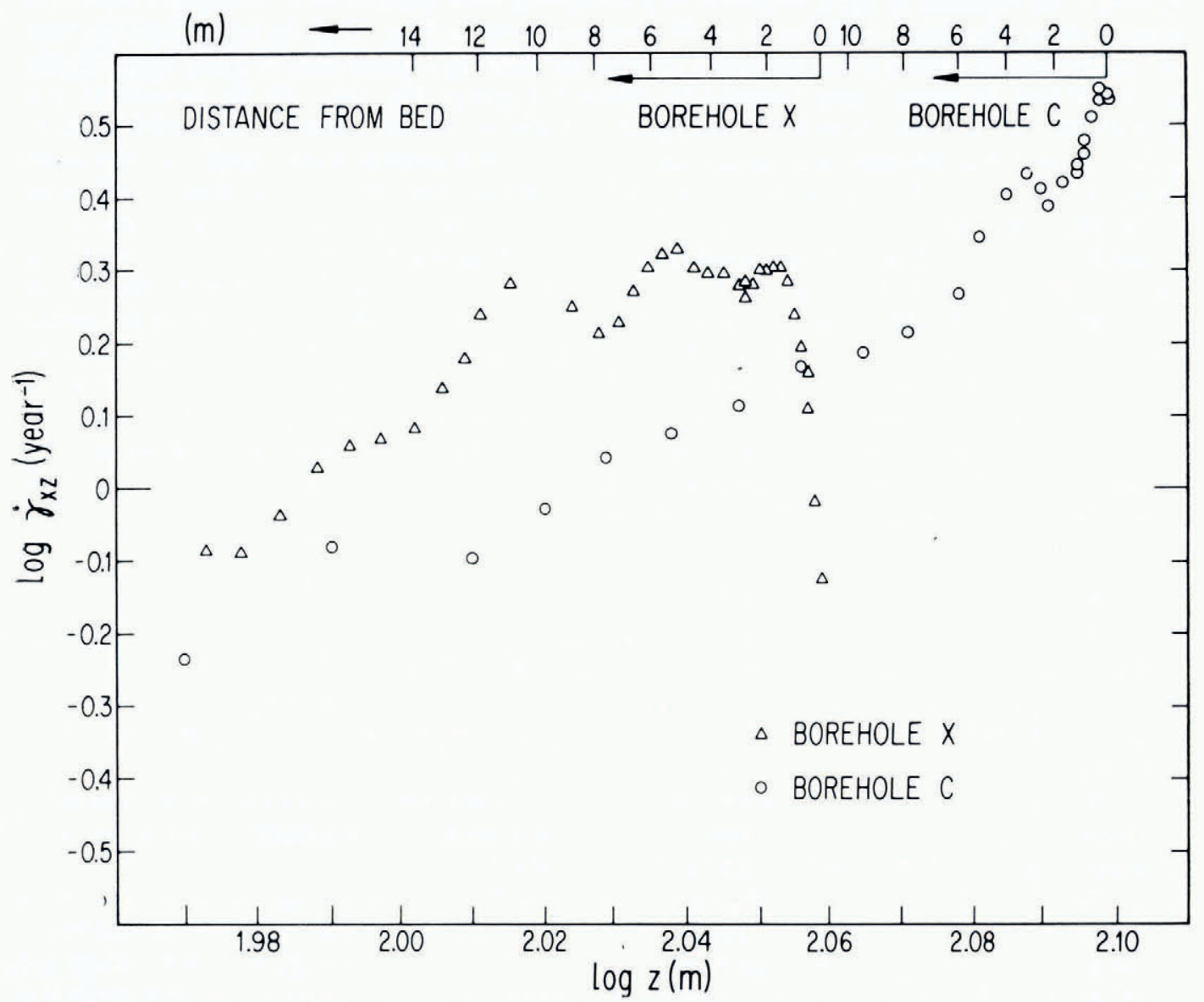

Fig. Io. Double logarithmic plot of shear strain-rate $\dot{\gamma}=\mathrm{d} u_{x} / \mathrm{d} z$ versus depth $z ; x$ is parallel to the surface, positive downslope, and $z$ is measured perpendicularly downward from the surface. At the top, distances above the bed (in meters) are given for reference.

* To the quoted error in this figure must be added an additional uncertainty due to the fact that an initial inclinometer survey, just after bore-hole completion, was not made for this hole, so that the initial hole must be assumed vertical. From our previous experience we know that this is a fairly good approximation. However, if the extent of initial non-verticality of hole $\mathrm{X}$ were the same as that measured in hole $\mathrm{C}$, an error of $0.2 \mathrm{~cm} / \mathrm{d}$ in the inferred sliding velocity for hole $\mathrm{X}$ could be produced. 
done to reach the actual bed, and confirmation that the bed has been reached can only be obtained with bore-hole photography. Considering the range in the thicknesses of "light debris" encountered in our different bore holes (Table I, column 4), we can estimate from the bore-hole deformations (Fig. 9) that sliding velocities obtained by the indirect method would be too large by 0.1 to $9 \mathrm{~cm} / \mathrm{d}$ because of failure to reach the bed by thermal drilling. The apparent sliding rate of about $6 \mathrm{~cm} / \mathrm{d}$ (annual average) obtained in our earlier measurements by the indirect method in the same area (Kamb and Shreve, I966) was probably falsified at least to some extent in this way.

The detailed behavior of the bore-hole deformations in the vicinity of the glacier bed is shown in Figure 1o, where the tilt measurements, expressed in terms of shear strain-rate parallel to the glacier surface, are plotted against depth beneath the surface, in a log-log plot. Leaving aside some irregularities in the data, the general trend of deformations in both holes $\mathrm{X}$ and $\mathrm{C}$ corresponds to shear strain-rates $\dot{\gamma}$ increasing with shear stress $\tau$ (assumed linear with depth) in a power-law relation $\dot{\gamma} \propto \tau^{n}$ with exponent $n \approx 5$. This is in agreement with earlier bore-hole deformation measurements in the vicinity (Kamb and Shreve, r966). Quite near the bed, however, some noteworthy anomalies occur (Fig. Io). In the lowermost $2 \mathrm{~m}$ of hole $\mathrm{X}$, the tilt rate decreases dramatically, while in the lowermost 2 to possibly $6 \mathrm{~m}$ in hole $\mathrm{C}$ there is a marked increase in tilt rate above the general trend higher in the hole. These anomalies imply that the basal shear stress in the vicinity of hole $\mathrm{X}$ was relieved locally, while the basal shear stress near hole $\mathrm{C}$ was locally enhanced. Relief of basal shear stress around hole X could be accomplished by partial ice-bed separation, in agreement with our photographic observation of an ice-bed gap (Section $5 \mathrm{c}$ ). The separation and relief of the basal drag stress should allow increased sliding, in conformity with the relatively high sliding rates observed in hole X (Table III). Conversely, enhancement of basal shear stress around hole C corresponds to greater ice-bed coupling and greater resistance to sliding, and hence conforms to the markedly low sliding velocity found in this hole. From the vertical extent of the anomalous strain-rates, we infer that ice-bed separation near hole X extended over an area of lateral dimensions $\approx 5 \mathrm{~m}$, and the enhanced ice-bed coupling or locally high roughness near hole $\mathrm{C}$ affected an area of dimensions $\approx \mathrm{I} 5 \mathrm{~m}$.

\section{Conclusions and interpretations}

I. Basal sliding velocities measured by bore-hole photography in holes completed to the bed by cable-tool drilling are confirmed by bore-hole inclinometry in these holes, to within the accuracies of the measurements. For observation periods of a month or less, the direct measurement of basal sliding by bore-hole photography gives more accurate results than does indirect measurement via inclinometry and surveying.

2. Indirect measurement is inherently unreliable in the absence of bore-hole photography to prove that the bed has been reached, and all earlier such measurements of sliding velocities in glaciers are called into serious question by our observations.

3. The observed sliding velocities are remarkably low. In a part of the glacier where a sliding rate of $6 \mathrm{~cm} / \mathrm{d}$ (annual average) was expected from earlier deformation measurements in thermally drilled bore holes, the observed summertime rates average $1.0 \mathrm{~cm} / \mathrm{d}$. They are much smaller than half the surface velocity of $15 \mathrm{~cm} / \mathrm{d}$. To the extent that the area studied is representative of temperate glaciers generally, we must reassess the role of the sliding phenomenon in the overall flow mechanics of these glaciers. The high sliding velocities, constituting a high proportion of the surface velocity, that have been observed in some glacier tunnels such as those in the Blue Glacier ice fall and in Glacier d'Argentière (Kamb and LaChapelle, I964, I968; Vivian and Bocquet, 1973) may be atypical because they occur in abnormal situations where there is extensive ice separation from the bed (basal cavitation) and where basal debris is relatively scarce or absent. 
4. The range of observed sliding rates is 0.3 to $3 \mathrm{~cm} / \mathrm{d}$, and the observed sliding directions range $30^{\circ}$ to either side of the direction of surface motion. Both lateral variations and time variations in the magnitude and direction of the sliding velocity are implied. Significant lateral variations in sliding velocity occur over distances of as little as $20 \mathrm{~m}$. The observed lateral variations do not fall into a systematic spatial pattern.

5. The glacier bed consists of bedrock overlain by unconsolidated rock debris (drift) forming a layer about $10 \mathrm{~cm}$ thick, which intervenes between bedrock and the base of the ice. We call this material the active subsole drift. Cable-tool drilling and bailing have thus far been incapable of removing the subsole drift thoroughly enough to reveal visibly the bedrock surface beneath; we infer its presence from drilling and bailing performance and from penetrometer tests.

6. The active subsole drift is actively involved in the sliding process. At times it remains relatively fixed while the ice moves over it, whereas at other times it is dragged along to some extent by the moving ice. Internal deformations within it include a rolling of the larger clasts where caught between fixed bedrock and moving ice. These motions suggest that a "ball bearing" mechanism in the subsole drift may contribute significantly to basal sliding.

7. Because of local internal deformations in the active subsole drift, the apparent sliding motions seen by bore-hole photography vary from point to point and are locally less than the full sliding velocity. Rolling clasts have an average motion half the sliding velocity.

8. In places the subsole drift is cohesionless and ice-free, while in other places it appears to contain some interstitial ice. In general it is not completely ice-saturated, and therefore forms an observably and mechanically distinct layer beneath the overlying debris-laden ice. Cable-tool drilling through the ice carves out solid bore-hole walls, which end abruptly at the top of the subsole drift. A major question is why the glacier ice fails to invade the subsole drift completely, which it could rapidly do by the action of regelation under the ice overburden pressure. We believe it necessary for the interstitial water pressure in the water-saturated subsole drift to be near the overburden pressure, for ice invasion to be prevented.

9. In some bore holes a gap a few centimeters thick is present between the base of the ice and the top of the subsole drift, showing that ice-bed separation has occurred under an ice thickness of $120 \mathrm{~m}$. In other holes no gap is present. The largest sliding velocities are observed in bore holes where a gap is present.

I0. The basal ice above the sole contains variable amounts of rock debris, which is present in a zone of thickness ranging from o. I to $16 \mathrm{~m}$ as encountered in our bore holes. This zone is impenetrable to bore holes made by electrothermal drilling alone, and sliding velocities determined from them by inclinometry will be erroneously large by 0.1 to $9 \mathrm{~cm} / \mathrm{d}$.

II. Ledge-like features in cohesive debris are occasionally formed at the base of the borehole walls, by a process in which masses of ice-containing debris in the subsole drift become caught between the bed and the ice sole and are pulled or sheared out across the bottom of the hole by the sliding motion.

12. We see no clear evidence of freezing or melting processes taking place at the bed in our bore holes, except for melting effects resulting from dissipation of heat from thermal drilling.

I3. The water level in the completed bore holes stands initially at a level that corresponds to a pressure at the bottom that is about $5 \%$ greater than the ice overburden pressure. This should ultimately cause ice-bed separation to occur except in areas of sufficiently large compressive stress concentration. The observed basal gaps may have been produced in this way.

I4. The subsole drift does not initially admit an appreciable inflow of the pressurized bore-hole water, as shown by continuation of high water levels and of turbid water at the bottom. Unless the subsole drift were fully ice saturated, which would be contrary to its existence as a material distinct from the basal ice, its required impermeability is extreme in relation to the most impermeable granular sediments. We infer the existence of interconnecting permeability barriers at the bed, such as areas where ice is in direct contact with 
bedrock, without intervening subsole drift. These barriers may be sufficient to hold the natural pore pressure in the subsole drift at a level near the overburden pressure.

I 5. The water pressure in subglacial conduits is essentially atmospheric. Most deep bore holes, especially those that reach the bed, ultimately establish a connection with the subglacial conduits, and their water level then drops greatly, in many cases to the bottom or nearly so. The water levels then fluctuate wildly owing to variations in water input and in flow capacity of constricted basal passageways from the bore holes to the subglacial conduits. One bore hole penetrated a subglacial stream.

16. The sliding velocity at one bore hole increased in four days from 1.5 to $3.0 \mathrm{~cm} / \mathrm{d}$. The increase correlated with the onset of the drop in water level in the hole. It may have been caused by ice-bed separation resulting from pressurization of the bed by the bore-hole water.

I 7. Turbidity of the basal water, which results from rock abrasion in the sliding process, is actively generated in the subsole drift and is introduced from the drift into the bottom of bore holes prior to the onset of water outflow from them.

18. Anomalously low shear strain-rates in the lowermost $2 \mathrm{~m}$ of one bore hole indicate local relief of basal shear stress, in harmony with the presence of a basal gap and the occurrence of a relatively high sliding rate $(1.4 \mathrm{~cm} / \mathrm{d})$. Anomalously high basal shear strain-rates in a second hole indicate local concentration of basal shear stress, which is consistent with the absence of a basal gap there and the very low observed sliding rate $(0.3 \mathrm{~cm} / \mathrm{d})$.

19. The observed conditions at and near the ice-bedrock interface, described above, do not closely correspond to the idealized state of affairs assumed in existing theoretical treatments of the basal sliding phenomenon. In particular, the abundance of rock debris and the lack of a clean ice-rock interface are features quite different from what is assumed in the theories. (A sliding theory by Morland (I976) includes a Coulomb-type friction term but does not consider the physical basis for it in terms of the behavior of debris-laden basal ice overlying subsole drift and bedrock.)

20. In searching for an explanation for why the actual sliding velocities are so low, we recognize three contributory aspects of the observed basal conditions. (I) The roughness of granular material $(\zeta \approx \mathrm{I})$ is so much higher than that of glacially smoothed bedrock $(\zeta<c$. 0.05) that if the subsole drift remains at times stationary on account of friction with the underlying bedrock, the sliding motion will be significantly impeded, even though the short roughness wavelengths for the subsole drift surface $(\approx$ io $\mathrm{cm}$ or less) tend to favor relatively rapid sliding by regelation. (2) The abundance of rock debris at the bed requires a significant involvement of rock friction in the sliding process, which adds to the support of the basal shear stress and therefore reduces the sliding from what would occur for clean ice moving over bedrock. (3) The low basal water pressure in subglacial conduits provides no enhancement of basal sliding through pressure-induced ice-bed separation.

21. Conditions that prevail naturally at the bed and in the subsole drift may be disturbed by bore holes drilled to observe them. Motions, water pressures, ice-bed separations, regelation phenomena, state of compaction and cementation, and character of the bedrock surface may be affected. We must recognize here a "subglacial uncertainty principle" that limits our ability to get information about the mechanics of basal sliding.

22. Each of our successful bore holes gave notably new and different types of observations, even though all were in a limited part of the glacier where conditions were seemingly uniform. It is safe to conclude that we have not yet sampled the full variety of phenomena that occur at the glacier bed in the sliding process.

\section{Acknowledgements}

This work was made possible by grants from the U.S. National Science Foundation. Cooperation of the U.S. National Park Service, Olympic National Park, is gratefully acknow- 
ledged. Helicopter transport of field equipment was capably provided by Mr Lee Roys, of Forks, Washington. We are grateful for able assistance in equipment preparation and field work by Henry Bell, Mike Carr, Keith Echelmeyer, Luise Engelhardt, Anne Harrison, Linda Kamb, Sasha Kamb, Rich Metcalf, Frank Shuri, Stuart Sipkin, Roger S. U. Smith, Kan Tanaka, Phil Taylor, and Craig Walker. We thank Barbara Niles for typing the manuscript. Charles F. Raymond, University of Washington, contributed heavily by carrying out much of the thermal boring and by providing a hot-water drill and inclinometer of new design for the 1976 field season.

MS. received 17 November 1977 and in revised form 25 January 1978

\section{REFERENCES}

Allen, C. R., and others. 1960. Structure of the lower Blue Glacier, Washington, by C. R. Allen, W. B. Kamb, M. F. Meier and R. P. Sharp. Fournal of Geology, Vol. 68, No. 6, p. 601-25.

Boulton, G. S. 1976. The origin of glacially fluted surfaces observations and theory. Fournal of Glaciology, Vol. 17 , No. 76 , p. $287-309$.

Budd, W. F. 1975. A first simple model for periodically self-surging glaciers. Fournal of Glaciology, Vol. 14, No. 70, p. 3-21.

Carol, H. 1947. The formation of roches moutonnées. Journal of Glaciology, Vol. 1, No. 2, p. 57-59.

Chamberlin, T. C. 1888 . The rock-scorings of the great ice invasions. U.S. Geological Survey. Seventh Annual Report, $1885-86$, p. $147^{-248 .}$

Doake, C. S. M. 1975. Glacier sliding measured by a radio-echo technique. Fournal of Glaciology, Vol. I5, No. 73, p. $89-93$.

Haefeli, R. 1951. Some observations on glacier flow. Journal of Glaciology, Vol. I, No. 9, p. 496-50o.

Harrison, W. D. 1972. Temperature of a temperate glacier. Journal of Glaciology, Vol. i i, No. 61, p. i 5-29.

Harrison, W. D., and Kamb, W. B. 1973. Glacier bore-hole photography. Journal of Glaciology, Vol. 1 2, No. 64, p. $129-37$.

Harrison, W. D., and Kamb, W. B. 1976. Drilling to observe subglacial conditions and sliding motion. (In Splettstoesser, J. F., ed. Ice-core drilling. Proceedings of a symposium, University of Nebraska, Lincoln, 28-3o August 1974. Lincoln, London, University of Nebraska Press, p. 37-43.)

Hodge, S. M. 1976. Direct measurement of basal water pressures: a pilot study. Fournal of Glaciology, Vol. 16, No. 74 , p. $205^{-1} 8$.

Kamb, W. B. r970. Sliding motion of glaciers: theory and observation. Reviews of Geophysics and Space Physics, Vol. 8, No. 4, p. $673-728$.

Kamb, W. B., and LaChapelle, E. R. 1964. Direct observation of the mechanism of glacier sliding over bedrock. Journal of Glaciology, Vol. 5, No. 38, p. $159-72$.

Kamb, W. B., and LaChapelle, E. R. 1968. Flow dynamics and structure in a fast-moving icefall. Transactions. American Geophysical Union, Vol. 49, No. 1, p. 312. [Abstract.]

Kamb, W. B., and Shreve, R. L. I963[a]. Structure of ice at depth in a temperate glacier. Transactions. American Geophysical Union, Vol. 44, No. I, p. ro3. [Abstract.]

Kamb, W. B., and Shreve, R. L. I $963[\mathrm{~b}]$. Texture and fabric of ice at depth in a temperate glacier. Transactions. American Geophysical Union, Vol. 44, No. 1, p. 103. [Abstract.]

Kamb, W. B., and Shreve, R. L. 1966. Results of a new method for measuring internal deformation in glaciers. Transactions. American Geophysical Union, Vol. 47, No. I, p. I9o. [Abstract.]

Klebelsberg, R. von. 1948-49. Handbuch der Gletscherkunde und Glazialgeologie. Wien, Springer-Verlag. 2 vols.

LaChapelle, E. R. I959. Annual mass and energy exchange on the Blue Glacier. Fournal of Geophysical Research, Vol. 64 , No. 4 , p. $443-49$.

Lliboutry, L. A. 1959. Une théorie du frottement du glacier sur son lit. Annales de Géophysique, Tom. I5, No. 2, p. $250-65$.

Lliboutry, L. A. 1968. General theory of subglacial cavitation and sliding of temperate glaciers. Fournal of Glaciology, Vol. 7, No. 49, p. $2 \mathrm{I}^{-}-58$.

McCall, J. G. 1952. The internal structure of a crique glacier: report on studies of the englacial movements and temperatures. Fournal of Glaciology, Vol. 2, No. 12, p. 122-31.

McKenzie, G. D., and Peterson, D. N. 1975. Subglacial cavitation phenomena: comments on the paper by R. Vivian and G. Bocquet. Fournal of Glaciology, Vol. I4, No. 71, p. 339-40. [Letter.]

Meier, M. F., and others. 1974. Flow of Blue Glacier, Olympic Mountains, Washington, U.S.A., by M. F. Meier, W. B. Kamb, C. R. Allen and R. P. Sharp. Journal of Glaciology, Vol. I3, No. 68, p. i87-2 12.

Morland, L. W. 1976. Glacier sliding down an inclined wavy bed with friction. Fournal of Glaciology, Vol. 17 , No. 77 , p. $463-77$.

Nye, J. F. 1969. A calculation on the sliding of ice over a wavy surface using a Newtonian viscous approximation. Proceedings of the Royal Society of London, Ser. A, Vol. 31 I, No. I 506, p. 445-67.

Nye, J. F. 1970. Glacier sliding without cavitation in a linear viscous approximation. Proceedings of the Royal Society of London, Ser. A, Vol. 315, No. 1522, p. $3^{81-403 .}$ 
Paterson, W. S. B. 1969. The physics of glaciers. Oxford, etc., Pergamon Press. (The Commonwealth and International Library. Geophysics Division.)

Paterson, W. S. B. 1970. The sliding velocity of Athabasca Glacier, Canada. Journal of Glaciology, Vol. 9, No. 55, p. $55-63$.

Post, A. S., and LaChapelle, E. R. [ $\left.{ }^{\mathrm{C}} \mathrm{I} 97 \mathrm{I}.\right]$ Glacier ice. Seattle, The Mountaineers; Seattle and London, University of Washington Press.

Raymond, C. F. 1971. Flow in a transverse section of Athabasca Glacier, Alberta, Canada. Fournal of Glaciology, Vol. 10, No. 58, p. $55^{-84}$.

Röthlisberger, H. I972. Water pressure in intra- and subglacial channels. Journal of Glaciology, Vol. I1, No. 62, p. $177^{-203}$.

Röthlisberger, H. $\quad$ I976. Thermal consequences of the pressure fluctuations in intra- and subglacial water drainage channels. Fournal of Glaciology, Vol. 16, No. 74, p. 309-10. [Abstract.]

Savage, J. C., and Paterson, W. S. B. 1963 . Borehole measurements in the Athabasca Glacier. Journal of Geophysical Research, Vol. 68, No. 15, p. $45^{21-36 .}$

Sharp, R. P. 1954. Glacier flow: a review. Bulletin of the Geological Society of America, Vol. 65, No. 9, p. 82 I-38.

Shreve, R. L., and Sharp, R. P. 1970. Internal deformation and thermal anomalies in lower Blue Glacier, Mount Olympus, Washington, U.S.A. Journal of Glaciology, Vol. 9, No. 55, p. 65-86.

Souchez, R. A., and Lorrain, R. D. 1975. Chemical sorting effect at the base of an Alpine glacier. Fournal of Glaciology, Vol. I4, No. 7I, p. 26I-65.

Souchez, R. A., and others. 1973. Refreezing of interstitial water in a subglacial cavity of an Alpine glacier as indicated by the chemical composition of ice, by R. A. Souchez, R. D. Lorrain and M. M. Lemmens. Fournal of Glaciology, Vol. 12, No. 66, p. 453-59.

Vivian, R., and Bocquet, G. 1973. Subglacial cavitation phenomena under the Glacier d'Argentière, Mont Blanc, France. Journal of Glaciology, Vol. 12, No. 66, p. 439-51.

Weertman, J. 1957. On the sliding of glaciers. Fournal of Glaciology, Vol. 3, No. 21, p. 33-38.

Weertman, J. 1964. The theory of glacier sliding. Fournal of Glaciology, Vol. 5, No. 39, p. $287-303$.

Weertman, J. I971. In defense of a simple model of glacier sliding. Journal of Geophysical Research, Vol. 76 , No. 26 , p. $6485-87$.

Weertman, J. 1972. General theory of water flow at the base of a glacier or ice sheet. Reviewes of Geophysics and Space Physics, Vol. ro, No. i, p. 287-333. 